\title{
Future agroclimatic conditions and implications for European grasslands
}

\author{
M. TRNKA ${ }^{1,2^{*}}$, J. BALEK ${ }^{1,2}$, M.A. SEMENOV ${ }^{3}$, D. SEMERÁDOVÁ ${ }^{1,2}$, M. BĚLÍNOVÁ ${ }^{1}$, \\ P. HLAVINKA ${ }^{1,2}$, J.E. OLESEN ${ }^{1,4,8}$, J. EITZINGER $^{5}$, A. SCHAUMBERGER ${ }^{6}$, P. ZAHRADNÍČEK ${ }^{1}$, \\ D. KOPECKÝ ${ }^{7}$, and Z. ŽALUD ${ }^{1,2}$
}

\author{
Global Change Research Institute CAS Brno CZ-60300, Czech Republic ${ }^{1}$ \\ Mendel University in Brno, Institute of Agrosystems and Bioclimatology, Brno CZ-61300, Czech Republic ${ }^{2}$ \\ Rothamsted Research, Harpenden, Herts, AL5 2JQ, UK \\ Aarhus University, Department of Agroecology, 8830 Tjele, Denmark ${ }^{4}$ \\ University of Natural Ressources and Life Sciences, Institute of Meteorology and Climatology, 1180 Wien, \\ Austria $^{5}$ \\ Agricultural Research and Education Centre Raumberg-Gumpenstein, 8952 Irdning-Donnersbachtal, Austria ${ }^{6}$ \\ Institute of Experimental Botany, CAS, Centre of the Region Haná for Biotechnological and Agricultural \\ Research, Olomouc, 77900, Czech Republic ${ }^{7}$ \\ iCLIMATE Interdisciplinary Centre for Climate Change, Aarhus University, 4000 Roskilde, Denmark ${ }^{8}$
}

\begin{abstract}
Grasslands play a significant role in livestock fodder production and thus, contribute to food security worldwide while providing numerous additional ecosystem services. However, how agroclimatic conditions and adverse weather events relevant for grasslands will change across the European grassland areas has not been examined to date. Using a single reference setup for soil and management over 476 European sites defined by climate stations, we show the probability of eight selected adverse weather events with the potential to significantly affect grassland productivity under climate change and how these events vary regionally across Europe. Changes in these eight key agroclimatic indicators create markedly specific spatial patterns. We found that by 2050 , the exposure of the south and west European grasslands to heat and drought may double in comparison with today and that the area with frequent occurrences of heat and drought will expand northwards. However, across Ukraine, Belarus, and the Baltic countries to southern Finland and Sweden, the likelihood of these events is likely to decrease. While changing cultivars and management strategies are unavoidable, shifting grassland production to other regions to reduce the risk may not be possible as the risk of adverse events beyond the key grassland-growing areas increases even further. Moreover, we found marked changes in the overall thermal and water regimes across European regions. The effect of adverse weather events in the future could be different in other regions of the world compared to regions in Europe, emphasizing the importance of conducting similar analyses for other major grassland producing regions. To mitigate the impact of climate change, new ways of maintaining grassland productivity need to be developed. These methods include more efficient selection of species mixtures for specific regions, including increased use of legumes and forbs; incorporation of new genetic resources, including the development of hybrid cultivars, such as Festulolium hybrids; and incorporation of state-of-the-art technologies in breeding programs and new grazing management.
\end{abstract}

Additional key words: climate change, extreme events, grassland productivity, LARS-WG.

Submitted 7 September 2020, last revision 1 January 2021, accepted 14 January 2021.

Abbreviations: GCM - global circulation model; EGR - effective global radiation; ETa - actual evapotranspiration; ETr - reference evapotranspiration; GCM - global circulation model; RCP - representative concentration pathway; TS10 - sum of temperatures above $10{ }^{\circ} \mathrm{C}$.

Acknowledgements: We acknowledge the World Climate Research Programme Working Group on Coupled Modelling responsible for CMIP5, and we thank the climate modelling groups for making available their model output. We would like to thank Luciano Pecetti (CREA-ZA, Italy), Marc Ghesquiere (INRA, France), Beat Boller (Agroscope, Switzerland), Mike Humphreys (IBERS, Wales), Susanne Barth (Teagasc, Ireland), Kristina Jaskune and Vilma Kemesyte (LAMMC, Lihuania), Liv Ostrem (NIBIO, Norway), and Joost Baert (ILVO, Belgium) for the revision of 'breeding recommendations'. The study made possible thanks to SustES - 'Adaptation strategies for sustainable ecosystem services and food security under adverse environmental conditions' CZ.02.1.01/0.0/0.0/16_019/00 00797) research program. Contributions and collaboration of MT, DK, PH, and ZZ have been also supported by AV21 support program 'Potraviny pro budoucnost'. Contribution by MAS was made possible thanks to grant-aided support to Rothamsted Research from the Biotechnology and Biological Sciences Research Council (BBSRC) through Designing Future Wheat [BB/P016855/1] and Achieving Sustainable Agricultural Systems [NE/N018125/1]. DK has been supported by the European Regional Development Fund OPVVV project "Plants as a tool for sustainable development" number CZ.02.1.01/0.0/0.0/16_019/0000827 supporting Excellent Research at CRH. We would like to thank to two anonymous reviewers for their helpful comments.

*Corresponding author; e-mail: mirek_trnka@yahoo.com 


\section{Introduction}

The current European grasslands have developed over millennia under natural conditions and/or in interaction with human management. Grasslands are characterized by multiple functions and values. In the context of agricultural food production, grasslands are mainly used for grazing livestock at pasture and for the production of hay and silage (Nita et al. 2019). Apart from their basic role in feeding herbivores and ruminants, grasslands also provide important ecosystem services, including soil erosion control, maintenance of species diversity, water retention, and water purification (Peeters 2008, Veen et al. 2009). Lesschen et al. (2014) distinguished between production grasslands, which are dedicated to producing fodder, and seminatural grasslands, which beside services listed above (e.g. providing forage for livestock) also provide biodiversity maintenance. For production grasslands, the main differentiating factors are between permanent and temporary grasslands and the level of intensification. Grasslands are very diverse in terms of management and yield and range from seminatural grasslands with low yields to highly productive agricultural grasslands, which include silage and hay fields and pastures under intensive production (Smit et al. 2008). Some of these intensive agricultural grasslands are rotated with arable crops in mixed livestock production systems (Herzog et al. 2006).

Arable land, which includes land for cereals and other annual crops, accounted for $60 \%$ of the utilized agricultural area in the EU-28 in 2013 (EUROSTAT 2019). Permanent grasslands, which are composed of pastures, meadows, and rough grazing areas, represented $34 \%$. Grasslands have a dominant share of agricultural land use in most mountainous European regions, such as in the Alps, supporting their high regional importance (Buchgraber et al. 2011). Similarly, the share of permanent grasslands of total agricultural land associated with livestock rearing (notably dairy and sheep farming) exceeded $50 \%$ in Luxembourg, Slovenia, the United Kingdom, and Ireland, while it was below $2 \%$ in Cyprus, Finland, and Malta. The regional shares of grassland are depicted in Fig. 1. Despite the fundamental economic, ecological, and aesthetic roles of grasslands, the overall area of permanent grasslands has been decreasing significantly since 1960s across EU-28 (Huyghe et al. 2014). This decrease has several negative environmental consequences, including biodiversity loss, increased greenhouse gas emissions and soil erosion.

The seasonality of grassland and forage production are primarily affected by temperature and soil moisture, which constrain the length and determine the intensity of the growing season. In most of Europe, the main seasonal trends in plant growth are determined by temperature. However, in southern and eastern Europe, summer growth is conditioned by the availability of soil moisture (Laidlaw et al. 2006, Trnka et al. 2006). In addition to temperature and the amount and timing of precipitation, grass production is also highly dependent on fertilization and land management, including grassland renewal, to maintain high productivity (Blanke et al. 2018).

Observed climate change trends and weather anomalies have affected grassland productivity across Europe (Kipling et al. 2016). The annual average temperature has increased in recent decades, with the greatest warming in northern Europe during winter and in southern Europe during summer. Precipitation has generally increased in northern and a large part of central Europe and has decreased in southern Europe. High temperature extremes and heavy precipitation events have become more frequent and more common across Europe (Seneviratne et al. 2012, Kovats et al. 2014). Increased drought stress and shortening of the active growing season, which in some regions become increasingly squeezed between cold winters and hot summers (Trnka et al. 2011), can affect water balance, grassland composition, biomass accumulation, and fodder quality, which have major consequences for feed production for livestock (Hoffstätter-Müncheberg et al. 2014, Huyghe et al. 2014).

Studies on the impacts of climate change on European grasslands have shown regionally specific responses and have demonstrated the necessity of analyzing both the overall shifts of agroclimatic conditions and the impacts of changes in weather variability. For example, Goliński et al. (2018) investigated the effects of climatic trends on grassland productivity in two contrasting locations in Europe. In central Poland, the dry matter yield of agriculturally improved grasslands had been reduced over time due to increasing temperatures, in particular, during summer. On the other hand, no significant effects on grassland yield from climate variables were found in northern Norway. In the Mediterranean region of Europe, reduction in rainfall increases the risks associated with overgrazing, which cause dramatic declines in the functional diversity of Mediterranean grasslands, potentially compromising their stability and resilience over time (Carmona et al. 2012). Walter et al. (2012) showed that increased rainfall variability may reduce grassland productivity and forage quality in central Europe, independent of mowing frequency. Craine et al. (2012) analyzed a long-term dataset of grassland productivity and found that drought, precipitation intensity and heat waves affected productivity differently throughout the growing season.

European grasslands are generally vulnerable to climate extremes, such as early or delayed snowmelt, heat waves, and droughts (Galvagno et al. 2013, De Boeck et al. 2016). The impacts of these extremes mainly depend on their intensity and timing (Sippel et al. 2016), ecosystem species composition and diversity, resilience of the grassland ecosystem, and interaction of biotic and abiotic factors (Hoover et al. 2014). Field observations (Inouye 2008) and model results (Rigby and Porporato 2008, Bennie et al. 2010) indicate that an earlier onset of the growing season without change in the timing of late frost events may even lead to an increased risk of damage to grassland species.

To assess and analyze grassland productivity and conditions, several grassland yield prediction and modeling approaches have been developed and applied in climate change impact studies in Europe (Graux et al. 2013, Höglind et al. 2013). These approaches have been applied 
not only to study the effects of climate change on grassland productivity but also to assess other effects, in particular, the impact of climate change on soil carbon storage in grasslands (Sándor et al. 2016, Chang et al. 2017). In some cases, these models have had difficulty dealing with climatic variability and extremes due to their complex effects on the grassland ecosystem, where resilience and recovery effects also play a key role (Ruppert et al. 2015, Kipling et al. 2016). Therefore, combining information from process oriented models maybe complemented by assessments of adverse weather events as shown in case of wheat (Trnka et al. 2015).

Outcomes from models of future climate conditions are an extremely valuable source of knowledge for grass breeders. Considering the outcrossing mode of reproduction and mostly perennial lifestyle of forage grass cultivars, development and registration take a long time (approximately ten years in the case of Italian ryegrass and 15 years for Festulolium). Similarly, an efficient breeding and management strategy considers that an individual cultivar will be commercialized for at least 20 to 30 years (Vladimir Cernoch, pers. comm.). Breeders must therefore take into the account the future climate conditions, for which they actually breed new cultivars. Prediction of the climatic conditions across Europe over the next 30 - 50 years is therefore a key component of the breeding process, which will allow the adoption of genetic resources with agricultural traits beneficial for coping with the likely impacts of climate change.

In this study, we seek to answer the following two research questions: to what extent will climate change alter the agrometeorological conditions that are important for grassland production stability (using a three cut regime and homogenous soil as the reference), and how will climate change affect the probability of selected adverse weather events.

\section{Materials and methods}

This paper first focuses on three types of agroclimatological characteristics relevant to grassland productivity in relation to temperature, water, and winter conditions. In the next step, the frequency of weather events that can be considered "adverse", i.e. conditions that are detrimental to grassland yield, is considered. The specific thresholds are described in Table 3 Suppl. We prefer the term "adverse" rather than "extreme", as the latter term is usually defined by the frequency of occurrence at a given site/region.

Study area and climate data: Simulation of agroclimatic conditions and adverse weather events for grasslands was performed for 476 European weather stations that represent the study domain (Fig. 1). In total, 36 European countries are represented in the study, covering the current European grassland-producing regions with the exception of Russia (Fig. 1C,D). The domain also covered all environmental zones (Fig. $1 B$ ) as defined by Metzger et al. (2005). Three global circulation models (GCM) from the CMIP5 ensemble (Fig. 1 Suppl., Table 1 Suppl.) were used to represent the known variability in the rate of temperature change and precipitation patterns. The model CSIRO-MK36 (CSIRO) was used as the central estimate, while GISS-E2-R-CC (GISS) represented a lower rate of temperature change and modest increase in dryness, and HadGEM2-ES (HadGEM) represented higher climate sensitivity with a hotter and dryer climate (Fig. 1 Suppl.).

The representative concentration pathway, RCP4.5, was used for the construction of local-scale climate scenarios with the climate models. The climate projections from GCMs were downscaled to local-scale daily weather by the $L A R S-W G 6.0$ weather generator using so called ELPIS dataset of site-specific parameters across Europe (Semenov et al. 2010, Semenov and Stratonovitch 2010). This database is based on combinations of GCMs and representative concentration pathway for downscaling. For each site and GCM, we generated 300 years of daily site-specific weather, representing the baseline scenario corresponding to 1981 - 2010, and 300 years for the future climate scenario corresponding to 2041 - 2060. In each simulation, the first 50 years were used to initialize the calculation of AgriClim soil moisture model, and the remaining 250 years of data were retained for subsequent analyses.

Agroclimate modeling: For each site, we used a predefined set of agroclimatic conditions and adverse events definitions. The entire set of the indicators was estimated using the AgriClim software (Trnka et al. 2011, 2014), with the parameters set according to those shown in Table 2 Suppl. and Table 3 Suppl. The grasslands were all assumed to be under a three-cut management regime to estimate the impact on the leaf area index and thus the crop specific coefficients. The cutting dates were determined automatically by dividing the growing season into three equal periods. The growing season was defined as the period with mean daily temperatures continuously above $5^{\circ} \mathrm{C}$, minimum temperatures greater than $-2^{\circ} \mathrm{C}$ and no snow cover. When calculating evapotranspiration, an adjustment for the atmospheric $\mathrm{CO}_{2}$ concentration was made by reducing the reference evapotranspiration by a scaling factor (Kruijt et al. 2008). The value of the scaling factor for 2050 was estimated to be 0.96 of the baseline value for $R C P 4.5$. We used one soil profile for all of the sites to enable comparison, with homogeneous soil properties assumed throughout the top and subsoil layers. The plant-available water at field capacity was assumed to be $270 \mathrm{~mm}$ for the entire profile (to a depth of $1.3 \mathrm{~m}$ ). We assumed a single free-draining soil with good waterholding properties and a relatively deep profile, allowing between-site comparisons of the climate signal.

Agroclimatic conditions: The agroclimatic characteristics relevant for grasslands and their likely development in the coming decades were divided into 1) temperature conditions during the growing season; 2) water availability; 3) cold season conditions; and 4) indicators of potential productivity. The vegetation season temperature conditions were described as the mean annual temperature (Tavg), sum of temperatures above $10{ }^{\circ} \mathrm{C}(\mathrm{TS} 10)$, and number of 
tropical days (i.e. number of days with a daily maximum temperature above $30^{\circ} \mathrm{C}$ ). The water regime parameters included the annual sum of precipitation, difference between the annual sum of precipitation and potential evapotranspiration, and number of days with reduced soil moisture availability in the topsoil, i.e. to a depth of $0.4 \mathrm{~m}$. The winter characteristics were described by the number of frost days (when the daily minimum temperature was below $0{ }^{\circ} \mathrm{C}$ ) and number of days with a snow cover above $3 \mathrm{~cm}$. The indicator of potential productivity (effective global radiation) was calculated as the sum of daily global radiation on days when the mean air temperature exceeded $5{ }^{\circ} \mathrm{C}$ without snow cover or frost occurrence and when plants were not severely limited by a lack of water. This indicator was assessed using the ratio of actual (ETa) and reference (ETr) evapotranspiration, with a minimum value of 0.4. Grassland growth on a given day was considered as not being significantly limited by water if the daily ratio of ETa to ETr exceeded 0.5. For this study, we deliberately chose a low threshold (0.4) to avoid overestimation of
A

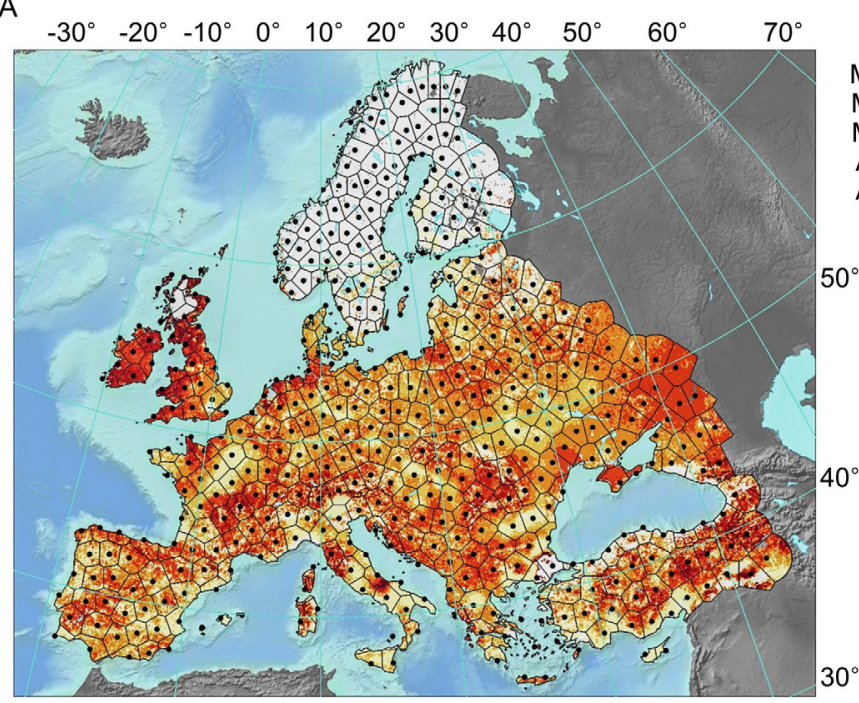

ELEVATION [m a.s.I.]

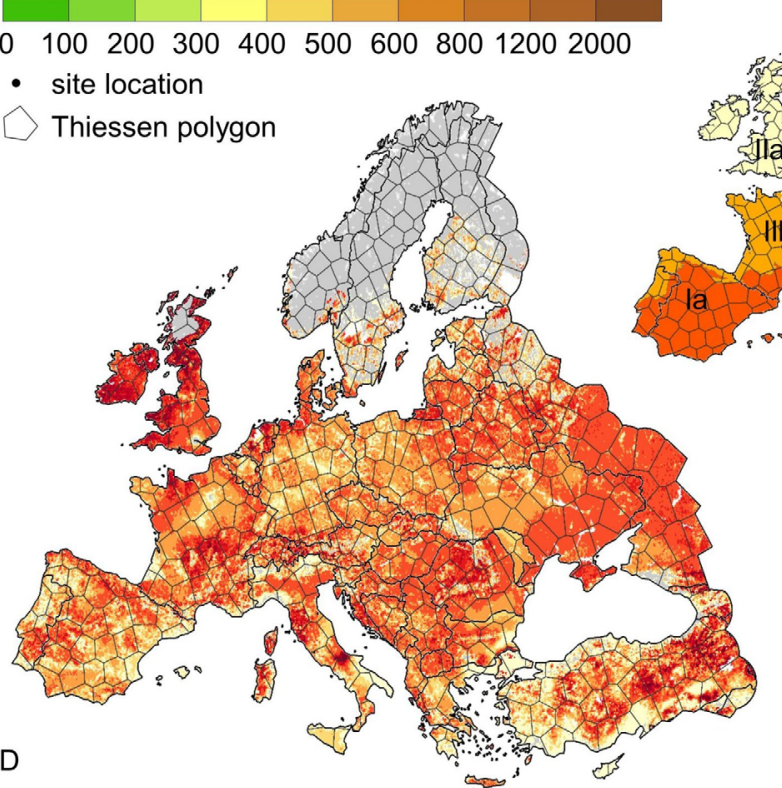

GRASS, PASTURES AND FORAGE AREA FRACTION

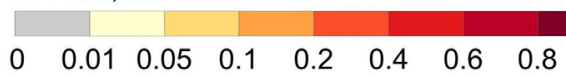

B

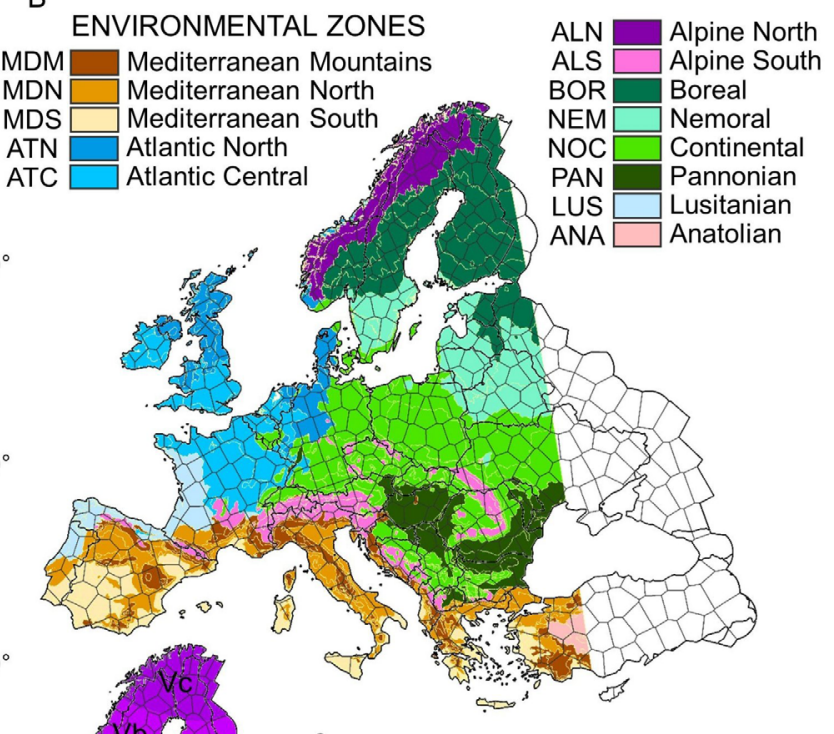

C

PEDO-CLIMATIC ZONES

Fig. 1. Altitude map of the domain of interest with the locations of the 476 weather stations used in the study (thin lines are Thiesen polygons) (A); environmental zones as developed by Metzger et al. (2005) covering most of the domain of interest (B); the grassland subregions considered in the study $(C)$; the proportion of the combined grassland, pasture and forage crop areas in each Thiesen polygon based on Monfreda et al. (2008) (D); and in panel $E$, the color and size of the circle correspond to the share of European grassland area per polygon. 
water shortage by the selected indices. Water shortage served as a component of a proxy for calculating potential productivity by summing global radiation only on days with temperature and soil moisture content permitting crop growth and development.

The indices were calculated for each of the climate stations, and Thiessen polygons (Fig. 1) were used to assign areas represented by each site. Then, the area of grasslands in each polygon was estimated using data from Monfreda et al. (2008). The weight of each polygon in the total grassland area (Fig. 1C) was calculated based (Fig. 1D) on gridded information on grassland acreage (Monfreda et al. 2008). Finally, to perform a more region-specific analysis, the data were aggregated into 13 subregions (Fig. 1C) for which the adaptation and breeding recommendations were formulated by the authors.

AgriClim software: The agroclimatic parameters listed in Table 2 Suppl. and Table 3 Suppl. were calculated using the AgriClim software package (Trnka et al. 2011). The software utilizes daily maximum and minimum temperatures, daily sums of global radiation and rainfall, mean daily wind speed and mean daily relative air humidity. For all ETr and ETa calculations, the grassland canopy was considered using the single crop coefficient (Kc) approach defined by Allen et al. (1998). Compared to the original methodology (Allen et al. 1998), AgriClim also accounts for the degree-day driven changes in Kc and grassland height. The model also distinguishes between solid and liquid precipitation (Trnka et al. 2010) and considers the effect of snowmelt on soil water content. An evaluation of the soil moisture routine has been presented by Hlavinka et al. (2011). The climate data and weather generator tools used to prepare the paper can be found at LARSWG (https://sites.google.com/view/lars-wg/) and the CMIP5 ensemble distribution site (http://pcmdi9.1lnl. gov/).

\section{Results}

Under the present climate, there is a considerable northsouth gradient in the mean annual temperature, with the lowest variability in the mean temperature in the southern and western parts of Europe (Fig. 2A). The projected temperature increase (Fig. $2 B-D$ ) is largest in the north according to all three models and most pronounced for the HadGEM model. Strong warming is also expected in the eastern and central parts of Europe. While the baseline spatial patterns of the TS10 compared to Tavg are very similar (Fig. 2E), they differ considerably for the future climate (Fig. $2 F-H$ ). The highest increase in the TS10 is expected in the south according to all the models, primarily because there are relatively few days with a mean temperature above $10{ }^{\circ} \mathrm{C}$ in the northern, central, and eastern parts of Europe compared to southern Europe. There is a substantial increase in the projected number of tropical days (i.e. days with Tmax above $+30{ }^{\circ} \mathrm{C}$ ), as shown in Fig. 2I-L. In many regions of Europe (e.g. central and south-western), the number of tropical days is likely to nearly double by 2050 , and a considerable increase compared to the current near-absence of these days is likely for areas of northern Germany, Poland, Denmark, and southern Scandinavia (Fig. $2 J-L$ ).

Grassland productivity is closely linked to sufficient and sustained water availability. Fig. 3 shows different aspects of water availability. There is a considerable precipitation gradient from west to east, with areas of low rainfall found across southern parts of Europe, throughout the central and eastern Balkans, Pannonia, and eastern Scandinavia. Fig. 3B-D demonstrates the large uncertainty in the GCM projections of precipitation change across Europe. While CSIRO and HadGEM projections tend to show a major precipitation decline in the western Mediterranean, the GISS model tends towards higher and more variable precipitation in the same region. Nevertheless, all three models agree on a decrease in precipitation in large parts of France and central Europe (to various degrees) and an increase in precipitation in most of Scandinavia. With the exception of the Mediterranean (for CSIRO and HadGEM), most areas are expected to display an increase in precipitation variability (Fig. $3 B-D$ ). Not surprisingly, the parameter combining the potential requirement of water and water availability, i.e. the annual water balance, shows clearer patterns in the expected shifts of agroclimatic conditions (Fig. 3E-H). Under all the GCMs, most of the analyzed European domain shows a tendency towards a more negative water balance and larger variability (Fig. $3 F-H$ ). Most of Scandinavia and the northern parts of the British Isles show the opposite tendency but also have markedly higher interannual variability. The tendency towards changes in the water balance is associated with an increased risk of drought or dry spells, as seen at Fig. 3I-L. The number of dry days will likely increase across most of Europe, with a consistent increase in the number of dry days in central Europe and the central Mediterranean (Fig. 3J-L).

With regards to the winter aspects of agroclimatic conditions (Fig. 4), the tendency towards milder winters in terms of a reduced number of frost days is clearly observed in all three GCMs. A much larger shift towards fewer frost days is observed in the eastern part of the domain (Fig. $4 B-D$ ), particularly in the north-east, where the number of frost days is largest under baseline conditions. The decrease in the number of frost days is accompanied by a significant reduction in the number of days with continuous snow cover, as presented in Fig. $4 E-H$. In many of the regions in the Baltic states, Belarus, and Scandinavia, the duration of snow cover might decrease by more than a month, indicating that the fraction of precipitation accumulated in snow will decrease also, which is an important factor for soil water supply in spring at the onset of the vegetation season.

The agroclimatic potential for grassland productivity may be best estimated through effective global radiation (EGR) during the growing season. An area of high EGR is concentrated in western Europe and the British Isles, with areas with very low EGR found both in the southern and northern parts of the domain. Central and eastern Europe as well as the southern part of Scandinavia represent 
areas with somewhat lower, but still favorably high, EGR (Fig.4I). Under the projected future climate (Fig. 4J-L), a major reduction of EGR is expected in the current areas of highest EGR, across the Mediterranean, through the
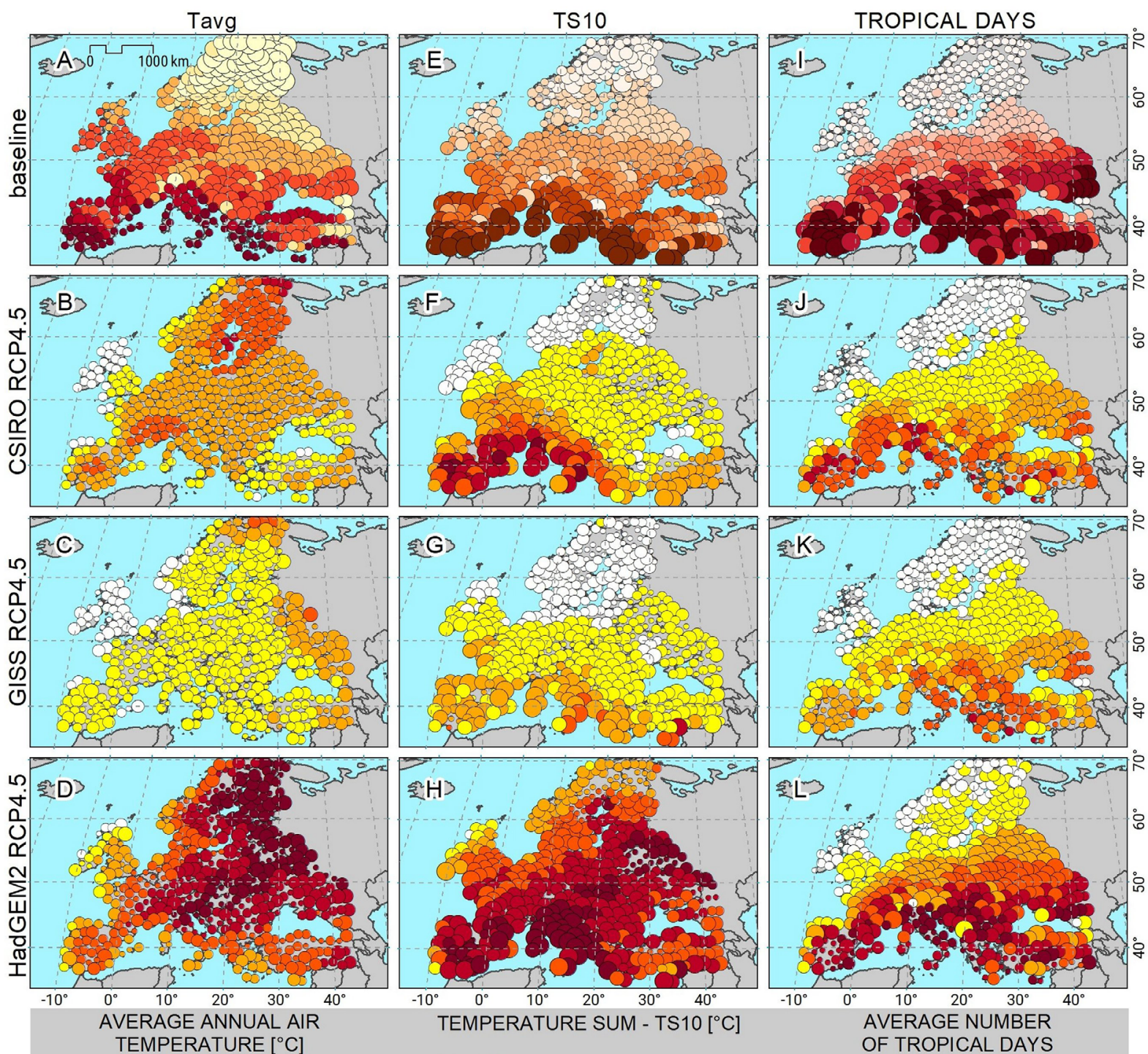

$A$ average temperature

$\begin{array}{ll}<4.0 & \text { STD } \\ 4.0-7.0 & 0.07-0.11 \\ 7.1-9.0 & 0.12-0.14 \\ 9.1-12.0 & 0.15-0.16 \\ 12.1-15.0 & \bigcirc 0.17-0.20 \\ 15.1-20.0 & \bigcirc 0.21-0.26 \\ \text { B-D average temperature anoma } \\ 0-1 & \\ 1.01-1.5 & \text { STD anomaly } \\ 1.51-2.0 & -0.03-0.01 \\ 2.01-2.5 & 0-0.009-0 \\ 2.51-3.0 & 0-0.01 \\ 3.01-3.5 & \bigcirc 0.011-0.04\end{array}$

TEMPERATURE SUM - TS10 [ $\left.{ }^{\circ} \mathrm{C}\right]$
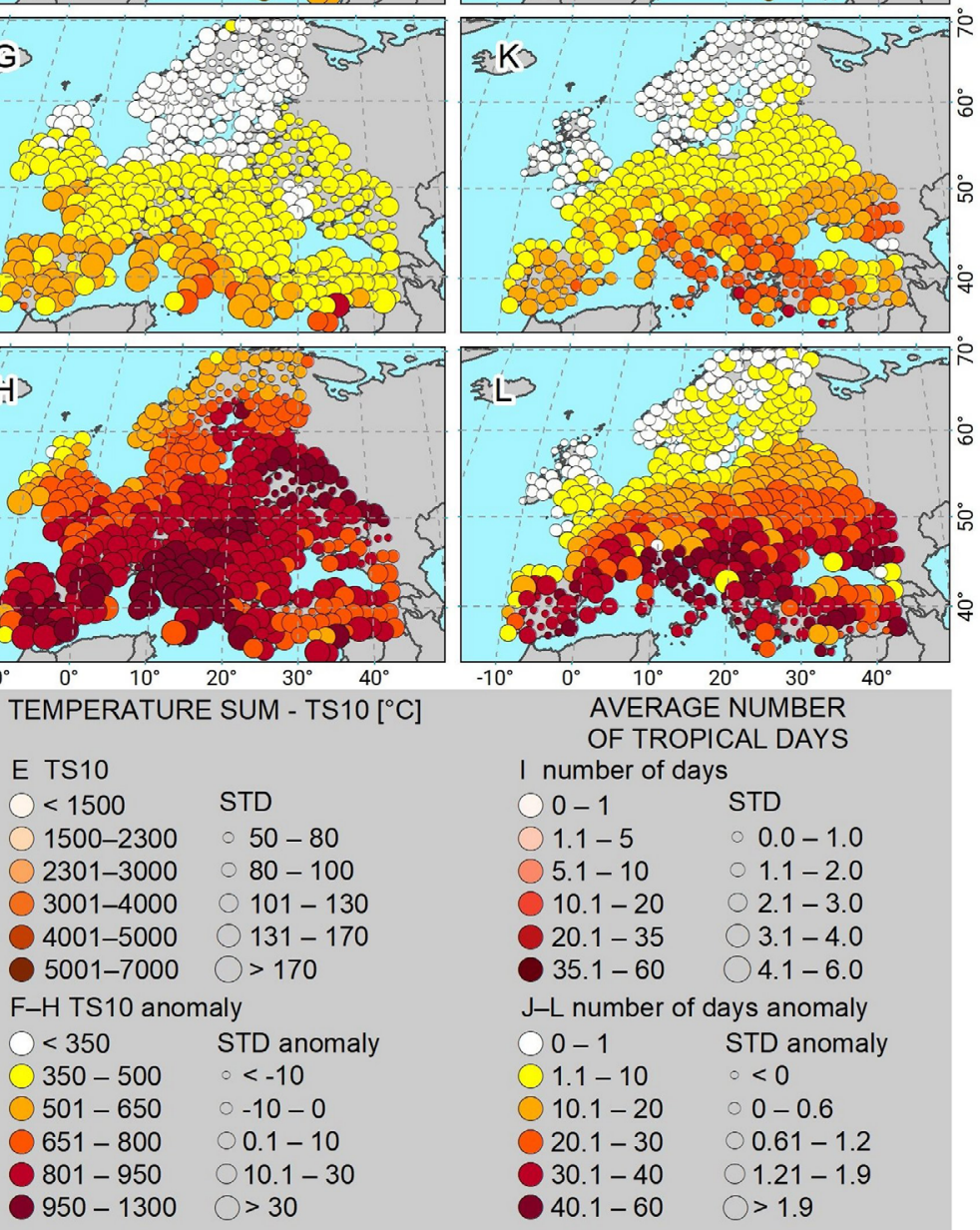

AVERAGE NUMBER OF TROPICAL DAYS

I number of days

$1.1-5 \quad 0.0-1.0$

$5.1-10 \quad 1.1-2.0$

$10.1-20 \bigcirc 2.1-3.0$

$20.1-35 \quad 3.1-4.0$

$35.1-60 \bigcirc 4.1-6.0$

$\mathrm{J}-\mathrm{L}$ number of days anomaly

O $0-1 \quad$ STD anomaly

$1.1-10 \quad<0$

$10.1-20 \quad 00-0.6$

$20.1-30 \quad 0.61-1.2$

$30.1-40 \bigcirc 1.21-1.9$

$40.1-60 \bigcirc>1.9$

Fig. 2. Baseline (1981 - 2010) values of the three selected parameters: mean annual temperature (Tavg, $A$ ); sum of the mean temperatures on days with a daily mean above $10{ }^{\circ} \mathrm{C}(\mathrm{TS} 10, E)$; number of tropical days, i.e. days with a daily maximum above $30^{\circ} \mathrm{C}$ (tropical days, I). The expected change compared to baseline is provided in the next three columns for the CSIRO-RCP4.5 (B,F,J), GISS-RCP4.5 $(C, G, K)$, and HadGEM-RCP4.5 (D,H,L) scenarios, which represent the period $2041-2060$. The size of the circle corresponds to the standard deviation (STD) of the given parameter over 300 individual yearly simulations. The STD of the anomaly represents an increase (when STD $>1.0$ ) or decrease (when STD $<1.0$ ) in the annual variability of the given indicator with respect to the baseline. 

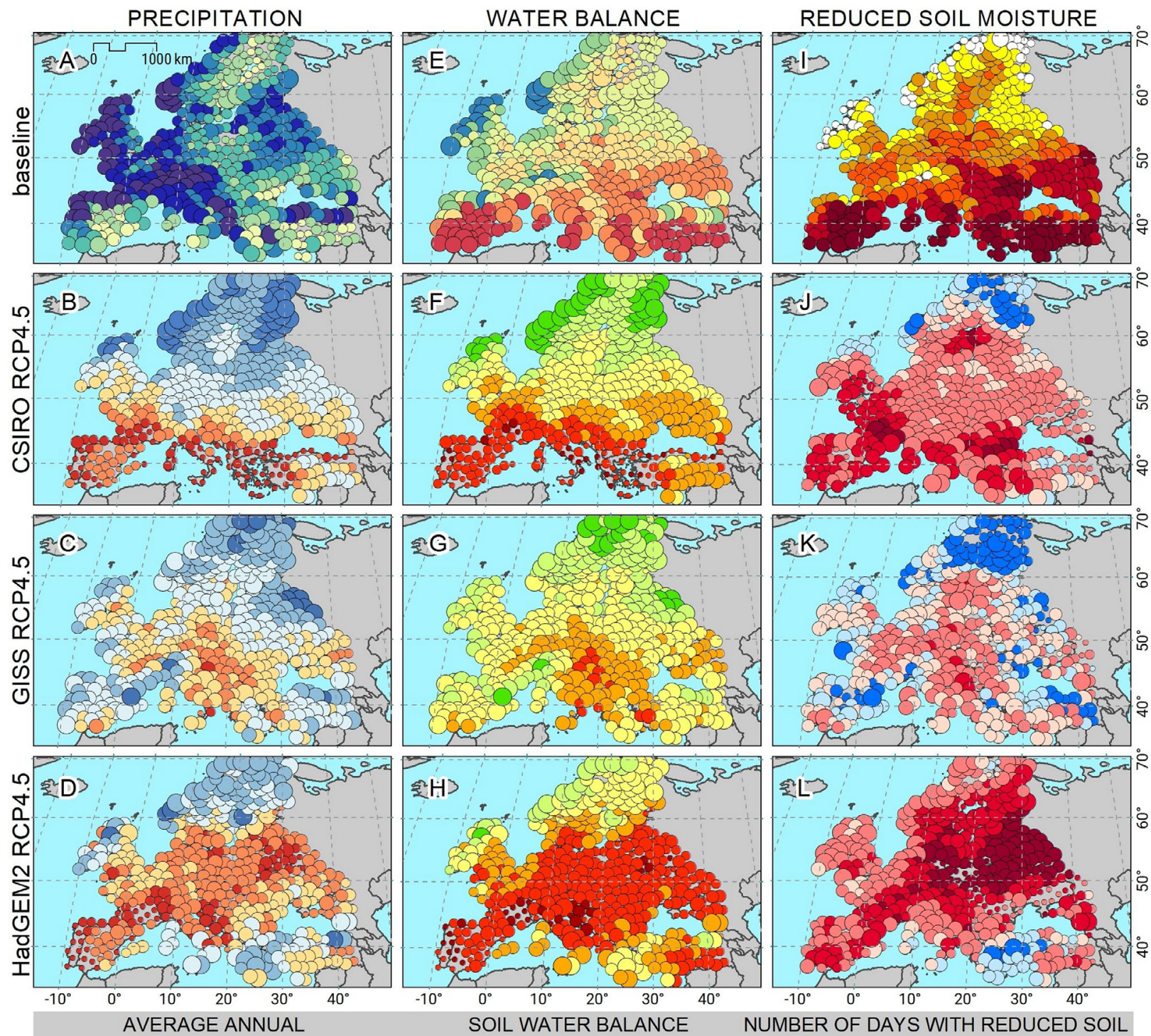

PRECIPITATION TOTAL $[\mathrm{mm}]$

A precipitation

$\begin{array}{ll}\text { A }<400 & \text { STD } \\ 400-500 & \circ 40-80 \\ 501-600 & \bigcirc 81-100 \\ 601-700 & \bigcirc 101-130 \\ 701-850 & \bigcirc 131-160 \\ >850 & \bigcirc>150 \\ \text { B-D precipitation total } \\ <-70 & \text { STD anomaly } \\ -70--30 & \circ<-20 \\ -29.9-0 & 0-20--10 \\ 0-30 & \bigcirc-9.9-0 \\ 30-70 & 0-10 \\ >70 & \bigcirc>10\end{array}$
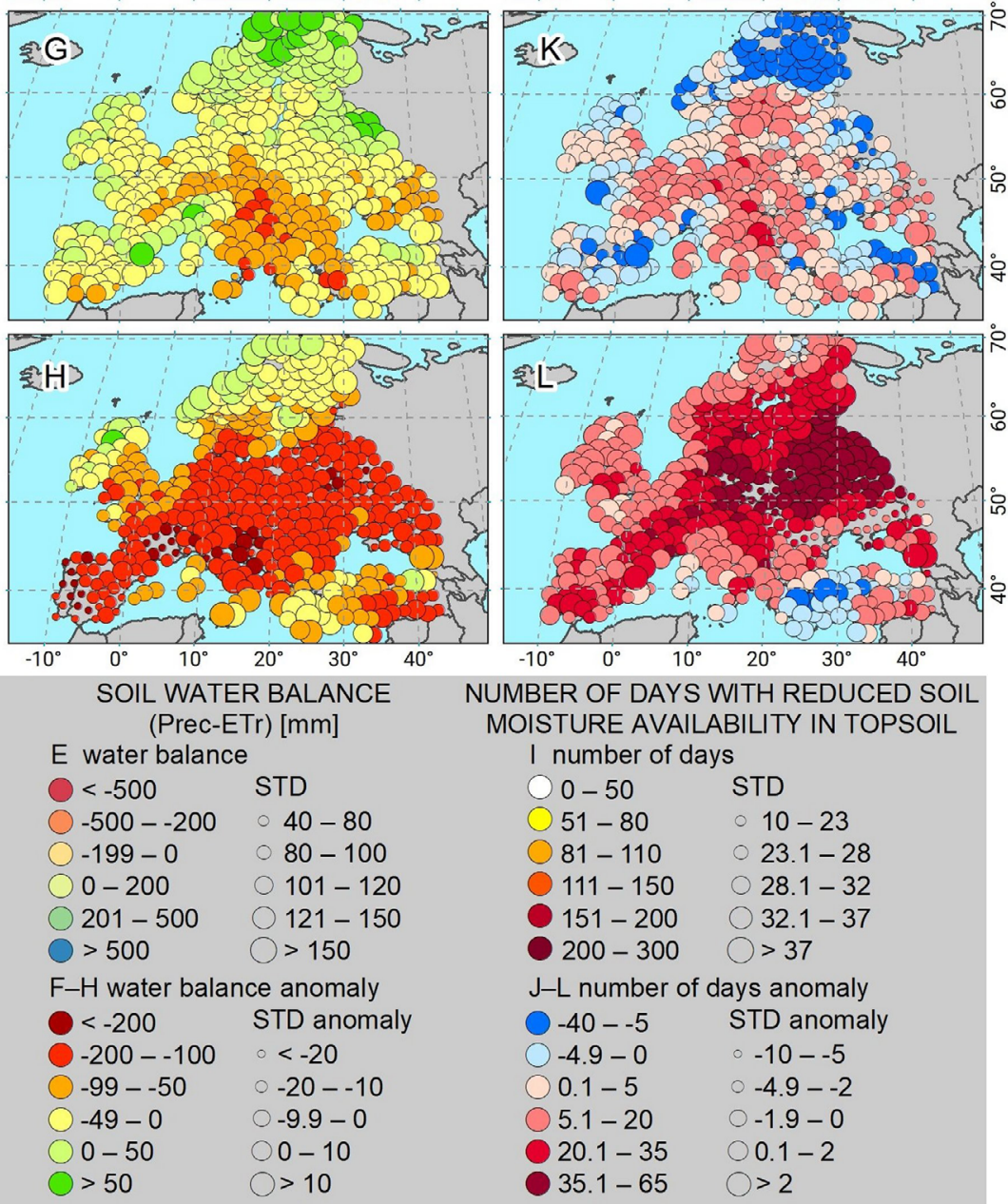

NUMBER OF DAYS WITH REDUCED SOIL MOISTURE AVAILABILITY IN TOPSOIL

I number of days
$00-50$
STD
$51-80$
$10-23$
$81-110$
$23.1-28$
$111-150$
$28.1-32$
$151-200 \quad 32.1-37$
$200-300 \quad>37$
$\mathrm{J}-\mathrm{L}$ number of days anomaly
$-40--5 \quad$ STD anomaly
$-4.9-0 \quad 0-10--5$
$0.1-5 \quad 0-4.9--2$
$5.1-20 \quad 0-1.9-0$
$20.1-35 \quad 0.1-2$
$\begin{array}{ll}20.1-35 & 0.1-2 \\ 35.1-65 & >2\end{array}$

Fig. 3. Baseline (1981 - 2010) values of the annual sum of precipitation (precipitation, $A$ ); climatological water balance calculated as the difference between the annual sum of precipitation and the sum of potential evapotranspiration (water balance, $E$ ); number of days in which the soil moisture in the topsoil is reduced below the point of decreased availability, i.e. days with a soil moisture less than $50 \%$ of the maximum available water holding capacity (reduced soil moisture, $I$ ). The expected change compared to baseline is provided in the next three columns for the CSIRO-RCP4.5 $(B, F, J)$, GISS-RCP4.5 $(C, G, K)$, and HadGEM-RCP4.5 $(D, H, L)$ scenarios, representing the period $2041-2060$. The size of the circle corresponds to the standard deviation (STD) of the given parameter over 300 individual yearly simulations. The STD of the anomaly represents an increase (when STD $>1.0$ ) or decrease (when STD $<1.0$ ) in the annual variability of the given indicator with respect to baseline. 

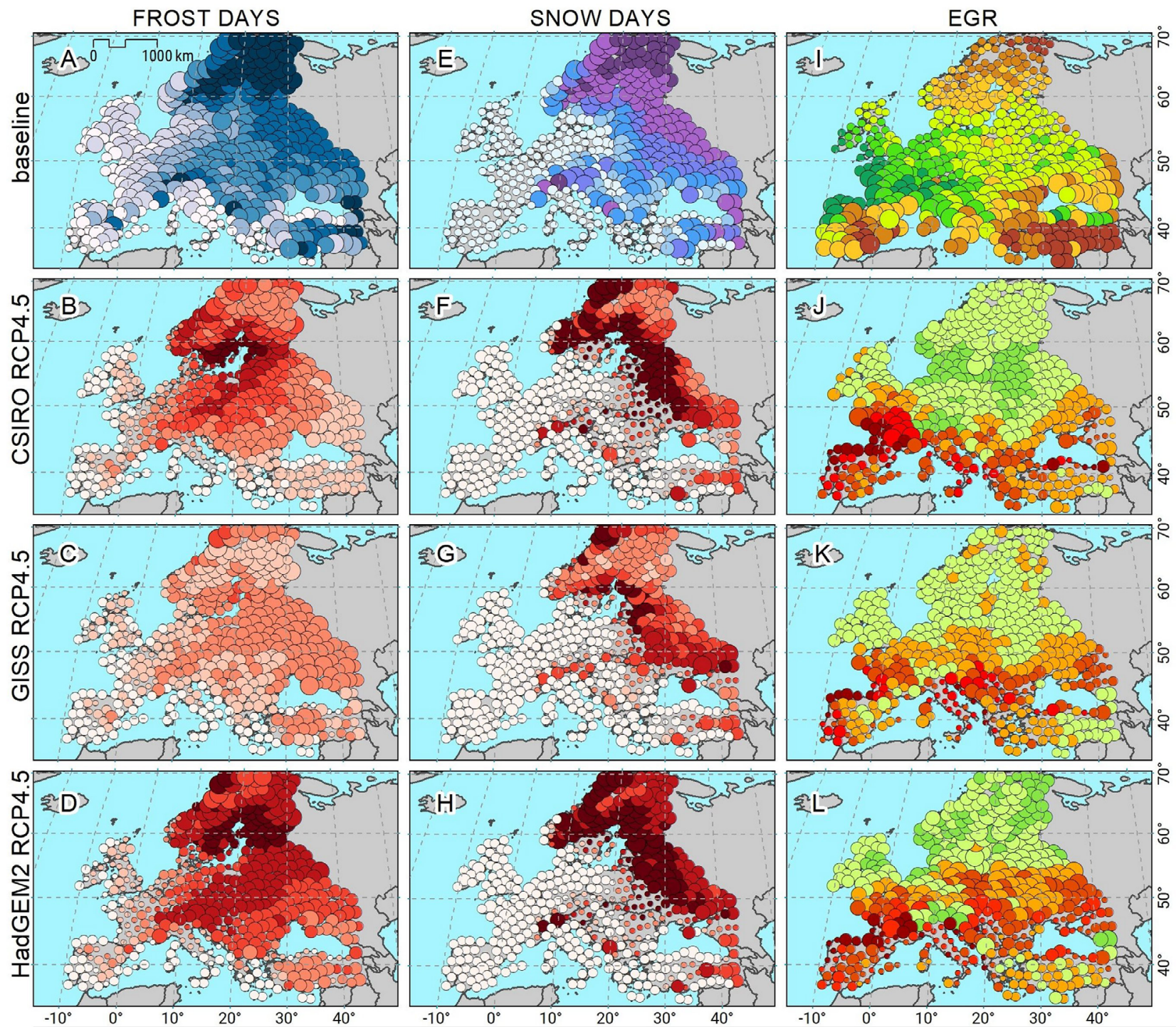

\begin{tabular}{|c|c|}
\hline \multicolumn{2}{|c|}{ NUMBER OF FROST DAYS } \\
\hline \multicolumn{2}{|c|}{ A number of days } \\
\hline $\begin{array}{l}0-30 \\
31-60 \\
61-90 \\
91-130 \\
131-170 \\
>170\end{array}$ & $\begin{array}{l}\text { STD } \\
0-2 \\
02.1-4 \\
4.1-5 \\
5.1-6 \\
6.1-8\end{array}$ \\
\hline \multicolumn{2}{|c|}{ B-D number of days anomaly } \\
\hline $\begin{array}{l}<-50 \\
-50--40 \\
-39--30 \\
-29--20 \\
-19--10 \\
-10-0\end{array}$ & $\begin{array}{l}\text { STD anomaly } \\
-2--1 \\
-1-0 \\
0-0.5 \\
0.5-1 \\
1-2\end{array}$ \\
\hline
\end{tabular}

NUMBER OF SNOW DAYS

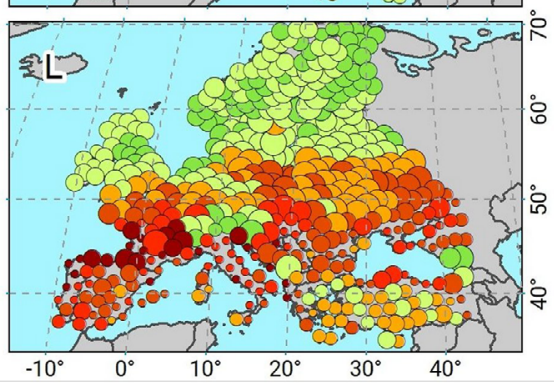

FECTIVE GLOBAL RADIATION (EGR)

E number of days

$\begin{array}{ll}0-5 & \text { STD } \\ 6-20 & \circ 0-3 \\ 21-50 & 3.1-10 \\ 51-100 & \bigcirc 10.1-15 \\ 101-150 & \bigcirc 15.1-22 \\ 151-200 & \bigcirc 22.1-30\end{array}$

I EGR [MJ m-2 $\left.\mathrm{d}^{-1}\right]$

560-1500 STD

$1501-1900 \circ 75-150$

$1901-2300 \bigcirc 151-250$

2301-2700 $\bigcirc 251-350$

$2700-3100 \bigcirc 351-450$

3101-3700 450-700

$\mathrm{F}-\mathrm{H}$ number of days anomaly I-J EGR anomaly

$<-50 \quad$ STD anomaly $-900--600$ STD anomaly

$-50--35 \circ<-5$

$-34--20 \quad 0-4.9-0$

$-19--10 \quad 0-4.9$

$\begin{array}{ll}-9--5 & 0.9-10\end{array}$

$\begin{array}{ll}-599--400 & 0<-60 \\ -399--200 & 0-59-0 \\ -199-0 & 00-50 \\ 0-200 & \bigcirc 50-100 \\ 200-300 & \bigcirc 100-250\end{array}$

Fig. 4. Baseline (1981 - 2010) values of the number of frost days, i.e. days with a daily minimum temperature below $0{ }^{\circ} \mathrm{C}$ (frost days, $A$ ); number of days with snow cover above $3 \mathrm{~cm}$ (snow days, $E$ ); sum of effective global radiation (EGR) during days with a daily mean temperature above $5{ }^{\circ} \mathrm{C}$ and daily minimum temperatures above $-2{ }^{\circ} \mathrm{C}$ and no occurrence of significant water stress (EGR, $I$ ). The expected change compared to baseline is provided in the next three columns for the CSIRO-RCP4.5 (B,F,J), GISS-RCP4.5 (C, $G, K)$, and HadGEM-RCP4.5 $(D, H, L)$ scenarios, representing the period 2041 - 2060. The size of the circle corresponds to the standard deviation (STD) of the given parameter over 300 individual yearly simulation. The STD of the anomaly represents an increase (when STD $>1.0)$ or decrease (when STD < 1.0) in the annual variability of the given indicator with respect to baseline. 
Balkan Peninsula, and in central Europe.

Under the present climate, the occurrence of weather conditions that adversely influence grassland production, yield stability and fodder quality differs greatly over the domain (Fig. 5A). Europe can be divided into three areas with different probabilities of adverse events. The first area, with a very small probability of adverse events, spans from southern Scandinavia through Denmark, northern and western Germany, Benelux, and France to the Pyrenees in the south and most of the British Isles in the north-west. An area with a higher probability of adverse event occurrence, but still below $50 \%$, covers most of eastern Germany and central Europe. The last area is on the borders of the domain, and some adverse weather conditions generally occur there each season. The core areas with a low probability of adverse events under the present climate are also those with large areas of grasslands and high fodder production. The projected impact of climate change on the probability of adverse weather events corresponds well among all three climate models (Fig. 5B-G). The majority of the "core" grassland area in Europe with the most suitable conditions will remain unaffected by adverse weather events and will still include most of the British Isles, southern Sweden and Norway, Denmark, and Benelux; large parts of western Germany; and eastern and central France. Eastern and north-eastern Europe will likely experience a significant decrease in the probability of adverse events, but as these regions suffer from frequent adverse events under baseline conditions, even large reductions will not alleviate the risk entirely (Fig. $5 B-D$ ). On the other hand, a significant increase in the probability of adverse weather events that would be damaging to grassland productivity can be seen in southern Europe and is associated with the northward expansion of heat and drought stressed areas. A significant increase in the projected adverse weather event probability is also visible in Ireland and Scotland as well as western France and western Spain.
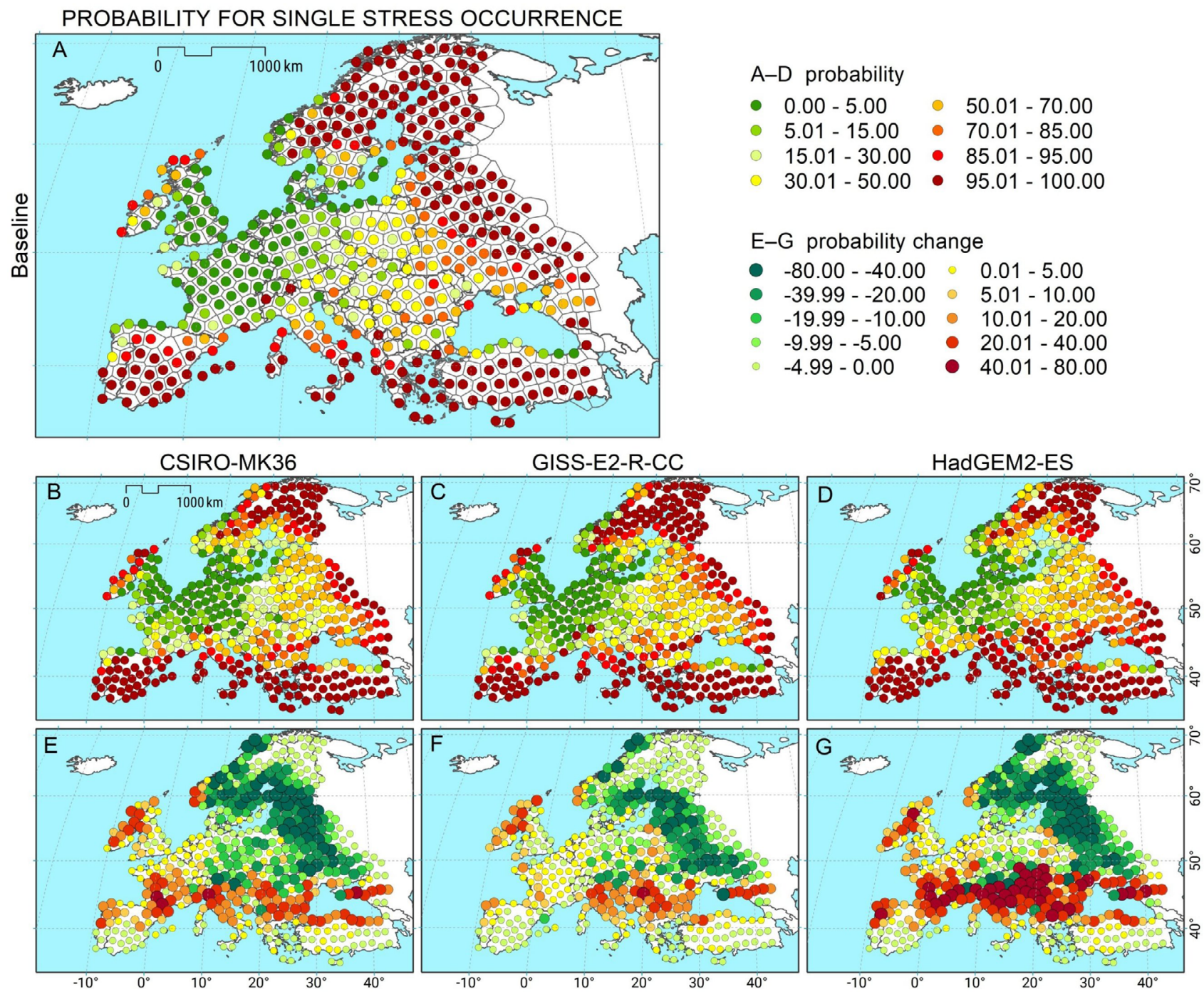

Fig. 5. Cumulative probability of the occurrence of a single adverse event under the baseline $(A)$ and projected climate scenarios $(B-D)$ as well as the change in the adverse event frequency $(E-G) . A$ - The baseline period $(1981-2010)$ and $B$ to $G$ - the climate scenarios (2035 - 2065) for CSIRO-RCP4.5 (B,E), GISS-RCP4.5 (C,F), and HadGEM-RCP4.5 (D). 
Fig. 6 shows that under current conditions, excess of water is the most frequent limitation for grassland production over much of the northwestern coastal area of the continent and the British Isles, while snow related limitations affect production in the northeastern and eastern part of the domain and in Alpine areas. Drought is projected to become the major limiting factor for grass production over most of the Mediterranean region, with heat stress dominating only for small areas in Turkey and central Europe. Low temperatures dominate as a cause of adverse events in parts of Scandinavia and central Europe. According to our estimates for future climatic conditions, overly wet conditions will become an increasing problem across the northwestern European grasslands (Fig. 6B-G), whereas snow-related issues together with the occurrence of inconveniently low temperatures will likely be a major concern in eastern and northeastern Europe as well as in the Alpine region (Fig. 6B-G). Even the relatively modest RCP4.5 emission scenario would lead not only to a sharp increase in the probability of heat stress (according to all GCMs) but also to drought. A major shift in the dominance of drought- and heat-related adverse events would occur across the whole Mediterranean region, but these events are also likely to increase for much of France, Germany, Denmark, Southern Sweden, Hungary, and the Czech Republic. There would also be an increase in drought as the single most important adverse event in eastern parts of the UK. The high degree of correspondence among all three GCMs indicates that the projections are quite robust.

Based on these results, a further aggregation of the

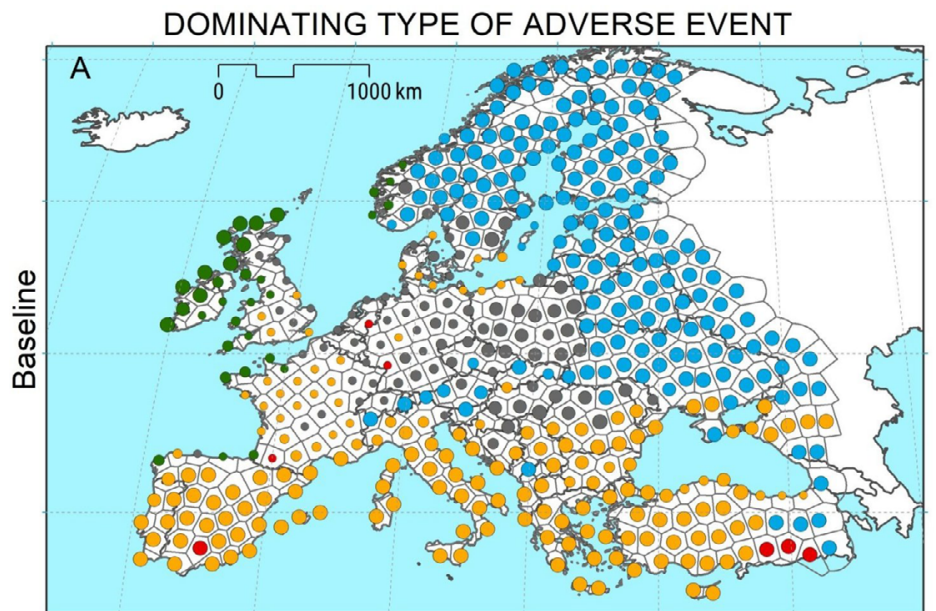

TYPE OF ADVERSE EVENT

drought

excess of water/ water logging

high temperatures

low temperatures

excess of snow

$A-D$ adverse event $E-G$ adverse with max change relative frequency relative frequency of occurence of occurence change

- 0 - 5.0

$0<-25.0$

- $5.1-10.0$

○ $10.1-25.0$

O $25.1-50.0$

$0>50.0 \%$

o $-24.9-0$

$0 \quad 0-10.0$

○ $10.1-25.0$

$\begin{array}{ll}0 & 10.1-25 \\ 0 & >25.0 \%\end{array}$
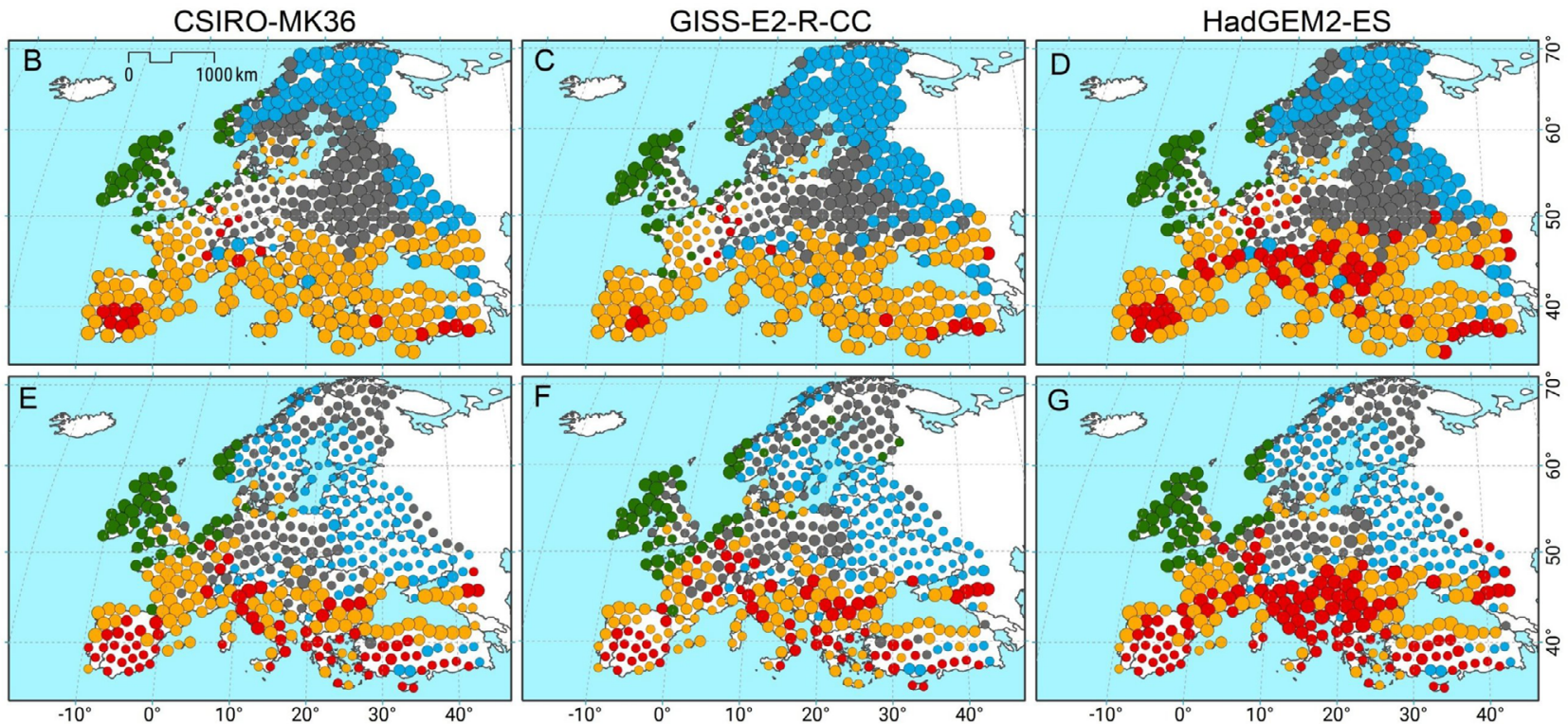

Fig. 6. Dominant type of adverse event and expected frequency for the baseline $(1981-2010)(A)$, and expected dominant types of adverse events and changes in frequencies under future $(2041-2060)$ climate conditions according to the three GCMs $(B-D)$, with the size of the circle corresponding to the event frequency. Panels $E$ - $G$ shows the type of adverse event that showed the largest change compared to the baseline for three considered GCMs: $A$ - the baseline period $(1981-2010)$ and $B$ to $G)$ - the climate scenarios $(2041$ - 2060) for CSIRO-RCP4.5 (B,E), GISS-RCP4.5 $(C, F)$, and HadGEM-RCP4.5 $(D, G)$. Note: individual adverse events are aggregated into groups based on Table 3 Suppl. 
expected changes for 476 stations into 13 predefined subregions was performed (Fig. $1 C$ ). For these subregions, the changes in the main agroclimatic parameters and frequency of adverse weather events are summarized in Table 4 Suppl. Then, using expert knowledge, recommendations for the breeding programs in each of the regions are made, including specific advice for Festulolium breeders (Table 4 Suppl.).

\section{Discussion}

Existing studies estimating the effect of climate change on grassland production rely on a set of either empirical or process-based crop models that are not optimized to recognize the impacts of the majority of adverse events considered here (Finger et al. 2010, Chang et al. 2016, Kipling et al. 2016, Ghahramani et al. 2019). This is the case for the former class of models because of their reliance on monthly or seasonal data, and it is also the case for the latter class of models because the model algorithms do not account fully (or at all) for the effects of adverse weather events, which can cause production decreases or quality deterioration (Kipling et al. 2016). Therefore, process-based grassland models may be complemented by estimates of adverse weather events made by simpler methods (e.g. as presented here) to obtain more realistic estimates of climate change impacts.

Some effort has been made towards improving grassland climate resilience (Černoch and Kopecký 2020, Humphreys and Zwierzykowski 2020), but there has been little emphasis on agroclimatic conditions or the adverse weather events relevant for grassland production and their ecosystem services. To date, research has focused on optimizing yield and quality under the prevailing climatic conditions without considering a broader range of climatic risks, as shown in a recent review by Ghahramani et al. (2019). Thus, targeting grassland management and genotypes that provide good matches to the environment still relies on monthly or even seasonal climatological parameters and often does not reflect the frequency of adverse events. Even in cases in which research focuses on extreme/adverse weather, there seems to be a bias towards certain types of events, which are addressed in detail without considering other coexisting potential threats. In recent years, substantial research efforts in breeding strategies have focused on the effect of drought and especially of heat stress (e.g. to improve stress tolerance of new crop or grass cultivars; Casler and Van Santen 2010). However, it is well known that grass production is not always affected by only one adverse event but rather by a combination of various events within one season, including their interactions (Kipling et al. 2016). For example, final yield may be affected not only by the frequency of days with high temperatures but also by the occurrence of late and severe frost without adequate snow cover or by overly wet and cool weather, which could enhance the occurrence of diseases. These interactions complicate the harvest and makes crop management more difficult.

Rising temperatures in cooler climates, associated with sufficient rainfall and an elevated $\mathrm{CO}_{2}$ concentration, would positively affect grassland productivity (Hopkins and Del Prado 2007), which would allow an increase in the grassland management intensity over Europe with higher than current potential annual grass forage yield, grazing capacity and livestock density and a shift in seasonal grazing capacity. However, the projected increase in the interannual variability of grassland productivity in some regions may reduce farmers' ability to take advantage of the increased long-term mean productivity in the face of more frequent and more severe declines in productivity (Chang et al. 2017). This risk is supported by projected increases in adverse weather event occurrence over some regions in our study, especially in the area just north of the Mediterranean (Figs. 5 and 6).

Dellar et al. (2018) evaluated the expected changes in yield, quality of pasture, and forage species caused by changes in air temperature, water availability, atmospheric $\mathrm{CO}_{2}$ concentration, and soil nitrogen content across different European regions. They concluded that areas with expected warmer and wetter conditions (in particular the northern region and parts of the Alpine and continental regions) can expect higher pasture yields but a reduction in forage $\mathrm{N}$ content, whereas warmer and drier areas (particularly southern Europe and parts of the continental region) would experience a reduction in both yield and $\mathrm{N}$ content. Our results support this spatial pattern in terms of the risks of drought and heat stress but also point to an increased occurrence of excessive rain or snow, which may pose challenges in some European grassland regions. This finding was also reported by Hopkins and Del Prado (2007), who concluded that increased temperatures and $\mathrm{CO}_{2}$ concentration have the potential to increase herbage growth and to favor legumes over grasses but that changes in seasonal precipitation would reduce these benefits, particularly in areas with low summer rainfall. Further implications for grasslands may arise from an increased frequency of extreme droughts, precipitation, storms, and other events. In some cases, there will even be changes in the dominant type of adverse weather events (Fig. 6), which may necessitate changes in grassland management strategies. Even if the frequency of adverse event occurrence decreases in some regions, a change in the dominant type of extreme event (Fig. $6 B-G$ ) can have serious short- to long-term implications (e.g. change of grassland composition) and could markedly change grassland productivity. While the risk of extended frost and/or snow risk can be alleviated by management practices, it is much more difficult to alleviate a decrease in water availability or risk of heat stress.

The increased occurrence of late frosts and frosts without snow cover, as shown by Fig. 2 Suppl., will likely negatively impact grasslands, in particular, in central and eastern Europe. Warmer extended autumns could shift the cold acclimation of plants to months when less light is available and impair the freezing tolerance of many grass species. Repeated freeze-thaw cycles, which are linked to warmer winters in central and northern Europe, also increase the risk of impermeable layers of ice forming in grasslands, which can cause substantial winter losses 
due to the anoxic conditions that arise under ice (Höglind et al. 2010, Dalmannsdottir et al. 2017). However, these conditions are not well covered by our indices of adverse weather conditions during winter. In addition, unstable winter and early spring temperatures with a risk of freezing can cause dehardening of plants, i.e. the loss of winter hardiness that protects plants during winter (Jørgensen et al. 2010).

Kreyling et al. (2012) investigated the local adaptation of grassland species to late frost on the continental scale and the influence of previous exposure to drought and warming on late frost sensitivity. They found that the biomass productivity of common European grass species decreased on average by approximately $20 \%$ in response to a single late frost event. However, there are still large uncertainties and research issues associated with the measuring the impacts of frost events on grassland productivity (Rapacz et al. 2014).

As indicated in Figs. 4E-H, Fig. 2 Suppl. and Fig. 3 Suppl., the snow cover duration will, in general, decrease substantially both in eastern Europe and in the mountain and highland areas of central Europe. The changes in snow melt timing and snow amount depend on the region and climate model. A sufficient snowpack of approximately 10 $\mathrm{cm}$ of freshly fallen snow is, in some regions, closely linked to grassland productivity, as it protects against severe frost damage, and its benefit has been shown especially in the cases of first and second cuts (Trnka et al. 2006, Peng et al. 2010). Xie et al. (2020) showed that snowmelt timing has a larger influence on the start of the season than snow cover depth. In addition, the timing and volume of snow cover are determining factors for water balance and earlier greening of grasslands during spring, which in turn, affects the annual carbon balance. Without snow cover, carbon dioxide assimilation in grasslands is controlled by temperature, with a threshold of approximately $5{ }^{\circ} \mathrm{C}$ for soil temperature (Zeeman et al. 2017). On the other hand, deepen winter snow cover enhances water balance and stabilizes plant community composition and productivity in temperate grasslands, which ultimately mitigate the impacts of chronic drought during the growing season in semiarid regions ( $\mathrm{Li}$ et al. 2020).

Summer heat waves negatively affect lowland grasslands in much of southern and central Europe, but in alpine grasslands, when water balance is nonlimiting, climate change will increase canopy greenness significantly by extending the green period in late summer and early autumn (Corona-Lozada et al. 2019). While Fig. $2 I-L$ indicates an increase in tropical days across most of Europe, the occurrence of more severe heat waves will be limited mostly to southern Europe. However, according to all the models and HadGEM in particular, severe heat waves may affect much of central Europe by 2050 (Fig. 4 Suppl.). While higher elevations appear less affected, the combined risk of heat and drought stress will also increase (Fig. 4 Suppl. and Fig. 5 Suppl.), which could negatively affect alpine grasslands (De Boeck et al. 2016). The increase in heat stress occurrence should be of concern even in these mountain systems (Cremonese et al. 2017).
Drought is a major natural hazard that can reduce plant productivity, lead to widespread plant dieback and restrict the geographical distribution of plant species (Tilman and El Haddi 1992). The effect of drought on grassland productivity is known to be significant even with relatively mild droughts (Trnka et al. 2006) and moderated by both nitrogen acquisition strategies and the nitrogen availability (Hofer et al. 2017a,b). Additionally, grassland types react differently to drought, as shown by Finn et al. (2018) or Wang et al. (2019). Their results indicate that different grassland types showed different resistance and resilience to drought disturbances with the latter confirming importance of species diversity in mitigating drought impacts. Natural grasslands in Europe have developed specific ecotypes adapted to the local temperature and drought conditions (BeierKuhnlein et al. 2011). The reaction to drought occurs at various levels, as demonstrated by De Vries et al. (2016), who quantified the root response of grassland species with contrasting ecological strategies to drought and assessed the changes in root biomass and traits. Reduced root biomass increased soil inorganic nitrogen availability, but did not directly affect root carbon exudation.

The increased $\mathrm{CO}_{2}$ concentration is, however, expected to increase the water use efficiency of the grasslands, which has been partially accounted for by using scaling factors according to the Kruijt et al. (2008) study. The most pronounced positive effect of $\mathrm{CO}_{2}$ on reducing drought frequency can be seen in areas where drought risk is increasing but rainfall is still relatively high (e.g. Central Europe, Alpine grasslands). In these regions even small increase of water use efficiency can moderate the increase of the evaporative demand. Despite some degree of resilience of grasslands to drought, the profound increase of the probability of drought events (Fig. 5 Suppl.) and reduced soil moisture availability (Fig. 3I-L) indicate a negative impact, especially in lowland areas. Finger et al. (2013) analyzed the economic impacts of summer drought on Swiss grassland yields and grassland composition and calculated up to a $37 \%$ annual yield loss in lowland and sub-Alpine localities of Switzerland, similar to findings reported by Brázdil et al. (2009) for the $20^{\text {th }}$ century droughts in the Czech Republic.

Changes in environmental factors such as temperature, rainfall and soil conditions are expected to alter the production conditions for temperate grasslands, affecting grassland productivity, production risks, fodder quality, and the frequency of occurrence of weed species in grasslands (Soussana and Lüscher 2007). Grassland yields in most European areas are expected to increase under future climatic conditions only if the benefits of the increasing atmospheric concentrations of $\mathrm{CO}_{2}$ are taken into account. Increases in the marginal productivity of nitrogen application induced by $\mathrm{CO}_{2}$ fertilization might lead to more intensive grassland management (Finger et al. 2010, Lazzaroto et al. 2010). Research strategies similar to the one developed by Taube et al. (2014) for grasslands in northwest Europe are necessary to maintain grassland sustainability. They recommended to focus research on sustainably intensifying grassland production 
and reducing the environmental impacts of the grasslandbased dairy industry. However, as our study shows, western and northwestern Europe are expected to experience much less change in agroclimate and adverse weather event frequencies than the rest of the continent, where such strategic studies would be even more necessary and have a stronger focus on measures to manage and cope with adverse weather events.

In general, productive grassland management targets an optimal balance among forage yield, forage quality, yield stability, and persistence (plant survival or reproduction). In the face of unstable and uncertain future climatic conditions, adaptation approaches are focused on the maintenance of a high diversity of cultivated forage species, implementation of a gene pool from wild relatives of crops to increase abiotic and biotic stress tolerance, optimization of defoliation and new fertilization strategies, improvement of soil management by irrigation or drainage, flexibility of grazing plans, and renovation or re-establishment of the grassland (Höglind et al. 2013, Golińska et al. 2016, Joyce et al. 2016, Klaus et al. 2016, Ergon et al. 2018). Higher species richness can enhance yield stability in both extensively and intensively managed grasslands and increase drought tolerance but only if there is a sufficient amount of water available (Ergon et al. 2018). In the context of species richness (grassland composition), permanent grasslands particularly contribute to a large degree of regional biodiversity, including the rich insect populations that is currently decreasing drastically across Europe (Deguines et al. 2014). Agricultural policy and adaptation strategies will need to consider these aspects in the future as well (Cole et al. 2020), especially in the context of grassland intensification strategies (Di Giulio 2001).

One of the adaptation strategies for reducing the risk of adverse weather events is stress avoidance through shifts in either time or space. Avoidance can be achieved by either escape from the stress at a given growing area through management strategies that shift the most sensitive growing stages to more suitable time of the year or by moving production elsewhere. However, our results show that moving production elsewhere could be problematic because areas where a decrease in adverse event frequency is expected (e.g. eastern Europe) usually show poor grassland growing conditions compared to areas where worsening conditions are expected (Fig. 4I). Avoiding the stress temporally by shortening the grassland production season inevitably leads to a lower amount of global radiation intercepted by plants and thus lower yield potential (unless the radiation-use efficiency of grassland species can be significantly improved). Avoidance in space can also be achieved by shifting grassland production to new growing areas, which may be less endangered by the projected increase in adverse event frequency and whose climate conditions may improve. The northward (and upward, i.e. to higher altitudes) expansion of grasslands into areas with a currently different land use (either forest or arable land) seems to be a potentially viable strategy from an agroclimatic point of view, but the available data indicate that conditions for such a change exist only in a few regions (Fig. 4J-L).

As shown by Trnka et al. $(2014,2015)$, the severity and frequency of some adverse events (e.g. drought stress) would, in general, be higher in soils with a low waterholding capacity, both under baseline and future climate conditions. The soil water holding capacity of the rooting zone used in this study was chosen to be above that of the majority of agricultural land. If we select actual soils (with water holding capacity in most cases much below 270 $\mathrm{mm}$ ), the probability of adverse events as defined in the study will increase. However, this study did not consider influence of soil conditions in general nor the moderating influence of the high underground water tables that sustain grasslands with water in some of the key grassland producing areas in Europe (e.g. in the lowlands or along rivers and streams). Under these conditions, grasslands would be capable of mitigating the impact of some adverse events (especially of drought stress) but could equally be subjected to flooding or prolonged periods with high water table, which would limit grass growth and prevent access to the grassland areas. Our study also did not consider irrigation, as the large majority of European grassland production is rainfed. While the use of irrigation would decrease the overall exposure of grassland production to drought and would eventually allow a longer growing season, it would be limited by existing water scarcity in some areas and by legal requirements for water extraction from water bodies (Monaghan et al. 2013).

We adopted a simplified scheme for calculating agroclimatic indices and adverse weather events. These indices have by nature general applicability and may not represent specific threats to plants in all cases, although the effects of frost and drought are probably well described. However, the risk of ice encasement through subsequent thawing and freezing, which may increase in much of northern and northeastern Europe, is much more difficult to model (Kipling et al. 2016). Therefore, there is a need for better data on the biophysical details of such situations to develop and validate models that can quantify these situations and project possible changes.

We focused on climate changes from the mid- $20^{\text {th }}$ century, and we thus opted to use a set of three GCMs from the CMIP5 ensemble, which are representative of the range of temperature and precipitation changes observed over the whole $C M I P 5$ ensemble. Since the differences between the representative concentration pathways $R C P 4.5$ and $R C P 8.5$ remain relatively small up to $2050, R C P 4.5$ was chosen as the reference. The method used for the GCM downscaling through $L A R S-W G$ does not allow to consider fully changes in the inter-annual variability (Semenov 2007) especially those caused by large scale changes in the atmospheric circulation. These changes could include changes in number of rainy days as a consequence of higher persistency of anticyclonic or blocking patterns or changes in strength of the North Atlantic Oscillation. Therefore, changes in the variability of adverse events presented in this study reflect shifts of the monthly means of key weather variables not their variability. There may well be further regional uncertainties in the projected impacts through climate modeling and the associated 
downscaling (Madsen et al. 2012), but we consider that the major uncertainties in projected climate changes have been captured.

\section{Conclusions}

Under future climate scenarios, all of the 476 investigated sites in Europe will experience marked changes in agroclimatic conditions important for grassland productivity. Most of the sites will display a higher risk of different types of adverse weather events than today and/ or higher chances of adverse weather event occurrence. Therefore, the target traits for grassland species and cultivars and strategies for grassland management should account for these spatially varying adverse events associated with climate change. Additionally, other ecosystem services provided by grasslands must be considered for future regional adaptation strategies, such as biodiversity maintenance, soil protection and soil carbon storage. Failing to address these challenges through proper adaptation measures could lead to a substantial reduction in European grassland productivity and fodder quality in the near future. Other key grassland-producing regions of the world could also be severely affected by adverse weather conditions, which calls for similar analyses to identify future risks for grassland productivity and ecosystem services to supplement impact assessments based on crop growth models.

\section{References}

Allen, R.G., Pereira, L.S., Raes, D., Smith, M.: Crop evapotranspiration (Guidelines for Computing Crop Water Requirements). - FAO Irrigation and Drainage Paper No. 56. FAO, Rome, 1998.

Beierkuhnlein, C., Thiel, D., Jentsch, A., Willner, E., Kreyling, J.: Ecotypes of European grass species respond differently to warming and extreme drought. - J. Ecol. 99: 703-713, 2011.

Bennie, J., Kubin, E., Wiltshire, A., Huntley, B., Baxter, R.: Predicting spatial and temporal patterns of bud-burst and spring frost risk in north-west Europe: the implications of local adaptation to climate. - Global Change Biol. 16: 15031514, 2010.

Blanke, J., Boke-Olén, N., Olin, S., Chang, J., Sahlin, U., Lindeskog, M., Lehsten, V.: Implications of accounting for management intensity on carbon and nitrogen balances of European grasslands. - PLoS ONE 13: e0201058, 2018.

Brázdil, R., Trnka, M., Dobrovolný, P., Chromá, K., Hlavinka, P., Žalud, Z.: Variability of droughts in the Czech Republic, 1881-2006. - Theor. appl. Climatol. 97: 297-315, 2009.

Buchgraber, K., Schaumberger, A., Pötsch, E.M., Krautzer, B., Hopkins, A.: Grassland farming in Austria - status quo and future prospective. - Grassland Sci. Eur. 16: 13-24, 2011.

Carmona, C.P., Azcárate, F.M., De Bello, F., Ollero, H.S., Lepš, J., Peco, B.: Taxonomical and functional diversity turnover in Mediterranean grasslands: interactions between grazing, habitat type and rainfall. - J. appl. Ecol. 49: 1084-1093, 2012.

Casler, M.D., Van Santen, E.: Breeding objectives in forages. In: Boller, B., Posselt, U.K., Veronesi, F. (ed.): Fodder Crops and Amenity Grasses. Handbook of Plant Breeding. Vol. 5. Pp. 115-136. Springer, New York 2010.
Černoch, V., Kopecký, D.: Drought tolerance and regrowth capacity revealed in the Festuca-Lolium complex. - Biol. Plant. 64: 561-568. 2020.

Chang, J., Ciais, P., Viovy, N., Vuichard, N., Herrero, M., Havlík, P., Wang, X., Sultan, B., Soussana, J.-F.: Effect of climate chnage, $\mathrm{CO}_{2}$ trends, nitrogen addition, and lan-cover and management intensity changes on the carbon balance of European grasslands. - Global Change Biol. 22, 338-350, 2016.

Chang, J., Ciais, P., Viovy, N., Soussana, J.F., Klumpp, K., Sultan, B.: Future productivity and phenology changes in European grasslands for different warming levels: implications for grassland management and carbon balance. - Carbon Balance Manage. 12: 11, 2017.

Cole, L.J., Kleijn, D., Dicks, L.V., Stout, J.C., Potts, S.G., Albrecht, M., Balzan, M.V., Bartomeus, I., Bebeli, P.J., Bevk, D., Biesmeijer, J.C., Chlebo, R., Dautarte, A., Emmanouil, N., Hartfield, C., Holland, J.M., Holzschuh, A., Knoben, N.T.J., Kovács-Hostyánszki, A., Mandelik, Y., Panou, H., Paxton, R.J., Petanidou, T., Pinheiro de Carvalho, M.A.A., Rundlöf, M., Sarthou, J.P., Stavrinides, M.C., Suso, M.J., Szentgyörgyi, H., Vaissière, B.E., Varnava, A., Vilà, M., Zemeckis, R., Scheper, J.: A critical analysis of the potential for EU Common Agricultural Policy measures to support wild pollinators on farmland. - J. appl. Ecol. 57: 681-694, 2020.

Corona-Lozada, M.C., Morin, S., Choler, P.: Drought offsets the positive effect of summer heat waves on the canopy greenness of mountain grasslands. - Agr. Forest Meteorol. 276: 107617, 2019.

Craine, J.M., Nippert, J.B., Elmore, A.J., Skibbe, A.M., Hutchinson, S.L., Brunsell, N.A.: Timing of climate variability and grassland productivity. - Proc. nat. Acad. Sci. USA 109: 3401-3405, 2012.

Cremonese, E., Filippa, G., Galvagno, M., Siniscalco, C., Oddi, L., Di Cella, U.M., Migliavacca, M.: Heat wave hinders green wave: the impact of climate extreme on the phenology of a mountain grassland. - Agr. Forest Meteorol. 247: 320-330, 2017.

Dalmannsdottir, S., Jørgensen, M., Rapacz, M., Østrem, L., Larsen, A., Rødven, R., Rognli, O.A.: Cold acclimation in warmer extended autumns impairs freezing tolerance of perennial ryegrass (Lolium perenne) and timothy (Phleum pratense). - Physiol. Plant. 160: 266-281, 2017.

De Boeck, H.J., Bassin, S., Verlinden, M., Zeiter, M., Hiltbrunner, E.: Simulated heat waves affected alpine grassland only in combination with drought. - New Phytol. 209: 531-541, 2016.

Deguines, N., Jono, C., Baude, M., Henry, M., Julliard, R., Fontaine, C.: Large-scale trade-off between agricultural intensification and crop pollination services. - Front. Ecol. Environ. 12: 212-217. 2014.

Dellar, M., Topp, C.F.E., Banos, G., Wall, E.: A meta-analysis on the effects of climate change on the yield and quality of European pastures. - Agr. Ecosyst. Environ. 265: 413-420, 2018.

De Vries, F.T., Brown, C., Stevens, C.J.: Grassland species root response to drought: consequences for soil carbon and nitrogen availability. - Plant Soil 409: 297-312, 2016.

Di Giulio, M., Edwards, P.J., Meister, E.: Enhancing insect diversity in agricultural grasslands: the roles of management and landscape structure. - J. appl. Ecol. 38: 310-319, 2001.

Ergon, Å., Seddaiu, G., Korhonen, P., Virkajärvi, P., Bellocchi, G., Jørgensen, M., Østrem, L., Reheul, D., Volaire, F.: How can forage production in Nordic and Mediterranean Europe adapt to the challenges and opportunities arising from climate change? - Eur. J. Agron. 92: 97-106, 2018.

Finn, J.A., Suter, M., Haughey, E., Hofer, D., Lüscher, A.: 
Greater gains in annual yields from increased plant diversity than losses from experimental drought in two temperate grasslands. - Agric. Ecosyst. Environ. 258: 149-153, 2018.

Finger, R., Gilgen, A.K., Prechsl, U.E., Buchmann, N.: An economic assessment of drought effects on three grassland systems in Switzerland. - Regul. environ. Change 13: 365374, 2013.

Finger, R., Lazzarotto, P., Calanca, P.: Bio-economic assessment of climate change impacts on managed grassland production. - Agr. Syst. 103: 666-674, 2010.

Galvagno, M., Wohlfahrt, G., Cremonese, E., Rossini, M., Colombo, R., Filippa, G., Julitta, T., Manca, G., Siniscalco, C., Morra Di Cella, U.: Phenology and carbon dioxide source/sink strength of a subalpine grassland in response to an exceptionally short snow season. - Environ. Res. Lett. 8: 025008, 2013.

Ghahramani, A., Howden, S.M., Del Prado, A., Thomas, D.T., Moore, A.D., Ji, B., Ates, S.: Climate change impact, adaptation, and mitigation in temperate grazing systems: a review. - Sustainability 11: 7224, 2019.

Golińska, B., Czerwiński, M., Goliński, P., Blecharczyk, A., Sawińska, Z.: Effect of climate changes on productivity of fresh meadows on the background of their different fertilization. - Fragmenta agron. 33: 18-28, 2016.

Goliński, P., Czerwiński, M., Jørgensen, M., Mølmann, J.A., Golińska, B., Taff, G.: Relationship between climate trends and grassland yield across contrasting European locations. Open Life Sci. 13: 589-598, 2018.

Graux, A.I., Bellochi, G., Lardy, R., Soussana, J.F.: Ensemble modelling of climate change risks and opportunities for managed grasslands in France. - Agr. Forest Meteorol. 170: 114-131, 2013.

Herzog, F., Steiner, B., Bailey, D., Baudry, J., Billeter, R., Bukácek, R., De Blust, G., De Cock, R., Dirksen, J., Dormann, C.F., De Filippi, R., Frossard, E., Liira, J., Schmidt, T., Stöckli, R., Thenail, C., Van Wingerden, W., Bugter, R.: Assessing the intensity of temperate European agriculture at the landscape scale. - Eur. J. Agron. 24: 165-181, 2006.

Hlavinka, P., Trnka, M., Balek, J., Semerádová, D., Hayes, M., Svoboda, M., Eitzinger, J., Možný, M., Fischer, M., Hunt, E., Žalud, Z.: Development and evaluation of the SoilClim model for water balance and soil climate estimates. - Agr. Water Manage. 98: 1249-1261, 2011.

Hofer, D., Suter, M., Buchmann, N., Lüscher, A.: Severe water deficit restricts biomass production of Lolium perenne L. and Trifolium repens L. and causes foliar nitrogen but not carbohydrate limitation. - Plant Soil 421: 367-380, $2017 \mathrm{a}$.

Hofer, D., Suter, M., Buchmann, N., Lüscher, A.: Nitrogen status of functionally different forage species explains resistance to severe drought and post-drought overcompensation. - Agric. Ecosyst. Environ. 236: 312-322, 2017 b.

Hoffstätter-Müncheberg, M., Merten, M., Isselstein, J., Kayser, M., Wrage-Mönnig, N.: Drought effects on herbage production of permanent grasslands in northern Germany. - Grassland Sci. Eur. 19: 106-108, 2014.

Höglind, M., Bakken, A.K., Jørgensen, M., Østrem, L.: Tolerance to frost and ice encasement in cultivars of timothy and perennial ryegrass during winter. - Grass Forage Sci. 65: 431-445, 2010.

Höglind, M., Thorsen, S.M., Semenov, M.A.: Assessing uncertainties in impact of climate change on grass production in Northern Europe using ensembles of global climate models. - Agr. Forest Meteorol. 170: 103-113, 2013.

Hoover, D.L., Knapp, A.K., Smith, M.D.: Resistance and resilience of a grassland ecosystem to climate extremes. Ecology 95: 2646-2656, 2014.
Hopkins, A., Del Prado, A.: Implications of climate change for grassland in Europe: impacts, adaptations and mitigation options: a review. - Grass Forage Sci. 62: 118-126, 2007.

Humphreys, M.W., Zwierzykowski, Z.: Festulolium, a century of research and breeding and its increased relevance in meeting the requirements for multifunctional grassland agriculture. Biol. Plant. 64: 578-590, 2020.

Huyghe, C., De Vliegher, A.D., Goliński, P.: European grasslands overview: temperate region. - Grassland Sci. Eur. 19: 29-40, 2014.

Inouye, D.W.: Effects of climate change on phenology, frost damage, and floral abundance of montane wildflowers. Ecology 89: 353-362, 2008.

Jørgensen, M., Østrem, L., Höglind, M.: De-hardening in contrasting cultivars of timothy and perennial ryegrass during winter and spring. - Grass Forage Sci. 65: 38-48, 2010.

Joyce, C.B., Simpson, M., Casanova, M.: Future wet grasslands: ecological implications of climate change. - Ecosyst. Health Sustain. 2: e01240, 2016.

Kipling, R.P., Virkajärvi, P., Breitsameter, L., Curnel, Y., De Swaef, T., Gustavsson, A.M., Hennart, S., Höglind, S., Järvenranta, K., Minet, J., Nendel, C., Persson, T., PiconCochard, C., Rolinski, S., Sandars, D.L., Scollan, N.D., Sebek, L., Seddaiu, G., Topp, C.F., Twardy, S., Van Middelkoop, J., Wu, L., Bellocchi, G.: Key challenges and priorities for modelling European grasslands under climate change. - Sci. total Environ. 566-567: 851-864, 2016.

Klaus, V.H., Hölzel, N., Prati, D., Schmitt, B., Schöning, I., Schrumpf, M., Solly, E.F., Hänsel, F., Fischer, M., Kleinebecker, T.: Plant diversity moderates drought stress in grasslands: implications from a large real-world study on ${ }^{13} \mathrm{C}$ natural abundances. - Sci. total Environ. 566-567: 215-222, 2016.

Kovats, R.S., Valentini, R., Bouwer, L.M., Georgopoulou, E., Jacob, D., Martin, E., Rounsevell, M., Soussana, J.F.: Europe. - In: Barros, V.R., Field, C.B., Dokken, D.J., Mastrandrea, M.D., Mach, K.J., Bilir, T.E., Chatterjee, M., Ebi, K.L., Estrada, Y.O., Genova, R.C., Girma, B., Kissel, E.S., Levy, A.N., MacCracken, S., Mastrandrea, P.R., White, L.L. (eds.): Climate Change 2014: Impacts, Adaptation and Vulnerability. Part B: Regional Aspects. Contribution of Working Group II to the Fifth Assessment Report of the Intergovernmental Panel on Climate Change. Pp. 1267-1326. Cambridge University Press, Cambridge - New York 2014.

Kreyling, J., Thiel, D., Simmnacher, K., Willner, E., Jentsch, A., Beierkuhnlein, C.: Geographic origin and past climatic experience influence the response to late spring frost in four common grass species in central Europe. - Ecography 35: 268-275, 2012.

Kruijt, B., Witte, J.P.M., Jacobs, C.M.J., Kroon, T.: Effects of rising atmospheric $\mathrm{CO}_{2}$ on evapotranspiration and soil moisture: a practical approach for the Netherlands. - J. Hydrol. 349: 257-267, 2008.

Laidlaw, A.S., Nesheim, L., Frame, J., Piñeiro, J.: Overcoming seasonal constraints to production and utilisation of forage in Europe. - Grassland Sci. Eur. 11: 29-43, 2006.

Lazzarotto, P., Calanca, P., Semenov, M., Fuhrer, J.: Transient responses to increasing $\mathrm{CO}_{2}$ and climate change in an unfertilized grass-clover sward. - Climat. Res. 41: 221-232, 2010.

Lesschen, J.P., Elbersen, B.S., Hazeu, G.W., van Doorn, A., Mucher, C.A., Velthof, G.L.: Defining and Classifying Grasslands in Europe - Task 1. - Wageningen Environmental Research, Wageningen 2014.

Li, P., Sayer, E.J., Jia, Z., Liu, W., Wu, Y., Yang, S., Wang, C., Yang, L., Chen, D., Bai, Y., Liu, L.: Deepened winter snow 
cover enhances net ecosystem exchange and stabilizes plant community composition and productivity in a temperate grassland. - Global Change Biol. 26: 3015-3027, 2020.

Madsen, M.S., Maule, C.F., McKellar, N., Olesen, J.E., Christensen, J.H.: Selection of climate change scenario data for impact modelling. - Food Additives Contam. A 29: 15021513, 2012.

Metzger, M.J., Bunce, R.G.H., Jongman, R.H., Mücher, C.A., Watkins, J.W.: A climatic stratification of the environment of Europe. - Global Ecol. Biogeogr. 14: 549-563, 2005.

Monaghan, J.M., Daccache, A., Vickers, L.H., Hess, T.M., Weatherhead, E.K., Grove, I.G., Knox, J.W.: More "crop per drop": constraints and opportunities for precision irrigation in European agriculture. - J. Sci. Food Agr. 93: 977-980, 2013.

Monfreda, C., Ramankutty, N., Foley, J.A.: Farming the planet: 2. Geographic distribution of crop areas, yields, physiological types, and net primary production in the year 2000. - Global Biogeochem. Cy. 22: GB1022, 2008

Nita, A., Hartel, T., Manolache, S., Ciocanea, C.M., Miu, I.V., Rozylowicz, L.: Who is researching biodiversity hotspots in Eastern Europe? A case study on the grasslands in Romania. PLoS ONE 14: e0217638, 2019.

Peeters, A.: Challenges for grasslands, grassland-based systems and their production potential in Europe. - Grassland Sci. Eur. 13: 9-24, 2008

Peng, S., Piao, S., Ciais, P., Fang, J., Wang, X.: Change in winter snow depth and its impacts on vegetation in China. - Global Change Biol. 16: 3004-3013, 2010.

Rapacz, M., Ergon, Å., Höglind, M., Jørgensen, M., Jurczyk, B., Østrem, L., Rognli, O.A., Tronsmo, A.M.: Overwintering of herbaceous plants in a changing climate. Still more questions than answers. - Plant Sci. 225: 34-44, 2014.

Rigby, J.R., Porporato, A.: Spring frost risk in a changing climate. - Geophys. Res. Lett. 35: L12703, 2008.

Ruppert, J.C., Harmoney, K., Henkin, Z., Snyman, H.A., Sternberg, M., Willms, W., Linstädter, A.: Quantifying drylands' drought resistance and recovery: the importance of drought intensity, dominant life history and grazing regime. Global Change Biol. 21: 1258-1270, 2015.

Sándor, R., Barcza, Z., Hidy, D., Lellei-Kovács, E., Ma, S., Bellochi, G.: Modelling of grassland fluxes in Europe: evaluation of two biogeochemical models. - Agr. Ecosyst. Environ. 215: 1-19, 2016.

Semenov, M.A.: Simulation of extreme weather events by a stochastic weather generator. - Climat. Res. 35: 203-212, 2007.

Semenov, M.A., Donatelli, M., Stratonovitch, P., Chatzidaki, E., Baruth, B.: ELPIS: a dataset of local-scale daily climate scenarios for Europe. - Climat. Res. 44: 3-15, 2010.

Semenov, M.A., Stratonovitch, P.: The use of multi-model ensembles from global climate models for impact assessments of climate change. - Climat. Res. 41: 1-14, 2010.

Seneviratne, S.I., Nicholls, N., Easterling, D., Goodess, C.M., Kanae, S., Kossin, J., Luo, Y., Marengo, J., McInnes, K., Rahimi, M., Reichstein, M., Sorteberg, A., Vera, C., Zhang, X.: Changes in climate extremes and their impacts on the natural physical environment. - In: Field, C.B., Barros, V., Stocker, T.F., Qin, D., Dokken, D.J., Ebi, K.L., Mastrandrea, M.D., Mach, K.J., Plattner, G.-K., Allen, S.K, Tignor, M., Midgley, P.M. (ed.): Managing the Risks of Extreme Events and Disasters to Advance Climate Change Adaptation. A Special Report of Working Groups I and II of the Intergovernmental
Panel on Climate Change (IPCC). Pp. 109-230. Cambridge University Press, Cambridge - New York 2012.

Sippel, S., Zscheischler, J., Reichstein, M.: Ecosystem impacts of climate extremes crucially depend on the timing. - Proc. nat. Acad. Sci. USA 113: 5768-5770, 2016.

Smit, H.J., Metzger, M.J., Ewert, F.: Spatial distribution of grassland productivity and land use in Europe. - Agr. Syst. 98: 208-219, 2008.

Soussana, J.F., Lüscher, A.: Temperate grasslands and global atmospheric change: a review. - Grass Forage Sci. 62: 127$134,2007$.

Taube, F., Gierus, M., Hermann, A., Loges, R., Schönbach, P.: Grassland and globalization - challenges for north-west European grass and forage research. - Grass Forage Sci. 69: 2-16, 2014.

Tilman, D., El Haddi, A.: Drought and biodiversity in grasslands. - Oecologia 89: 257-264, 1992.

Trnka, M., Eitzinger, J., Gruszczynski, G., Buchgraber, K., Resch, R., Schaumberger, A.: A simple statistical model for predicting herbage production from permanent grassland. Grass Forage Sci. 61: 253-271, 2006.

Trnka, M., Hlavinka, P., Semenov, M.A.: Adaptation options for wheat in Europe will be limited by increased adverse weather events under climate change. - J. roy. Soc. Interface 12: $20150721,2015$.

Trnka, M., Kocmánková, E., Balek, J., Eitzinger, J., Ruget, F., Formayer, H., Hlavinka, P., Schaumberger, A., Horáková, V., Možný, M., Žalud, Z.: Simple snow cover model for agrometeorological applications. - Agr. Forest Meteorol. 150: $1115-1127,2010$.

Trnka, M., Olesen, J.E., Kersebaum, K.C., Skjelvåg, A.O., Eitzinger, J., Seguin, B., Peltonen-Sainio, P., Rötter, R., Iglesias, A., Orlandini, S., Dubrovský, M., Hlavinka, P., Balek, J., Eckersten, H., Cloppet, E., Calanca, P., Gobin, A., Vučetić, V., Nejedlik, P., Kumar, S., Lalic, B., Mestre, A., Rossi, F., Kozyra, J., Alexandrov, V., Semerádová, D., Žalud, Z.: Agroclimatic conditions in Europe under climate change. - Global Change Biol. 17: 2298-2318, 2011.

Trnka, M., Rötter, R.P., Ruiz-Ramos, M., Kersebaum, K.C., Olesen, J.E., Žalud, Z., Semenov, M.A.: Adverse weather conditions for European wheat production will become more frequent with climate change. - Nat. Clim. Change 4: 637 643, 2014.

Veen, P., Jefferson, R., De Smidt, J., Van der Straaten, J. (ed.): Grasslands in Europe of High Nature Value. - KNNV Publishing, Zeist 2009.

Walter, J., Grant, K., Beierkuhnlein, C., Kreyling, J., Weber, M., Jentsch, A.: Increased rainfall variability reduces biomass and forage quality of temperate grassland largely independent of mowing frequency. - Agr. Ecosyst. Environ. 148: 1-10, 2012.

Wang, Q., Yang, Y., Liu, Y., Tong, L., Zhang, Q.P., Li, J.: Assessing the impacts of drought on grassland net primary production at the global scale. - Sci. Rep. 9: 1-8, 2019.

Xie, J., Jonas, T., Rixen, C., De Jong, R., Garonna, I., Notarnicola, C., Asam, S., Schaepman, M.E., Kneubühler, M.: Land surface phenology and greenness in Alpine grasslands driven by seasonal snow and meteorological factors. - Sci. total Environ. 725: 138380, 2020.

Zeeman, M.J., Mauder, M., Steinbrecher, R., Heidbach, K., Eckart, E., Schmid, H.P.: Reduced snow cover affects productivity of upland temperate grasslands. - Agr. Forest Meteorol. 232: 514-526, 2017. 